\title{
Traditional Foods From Maize (Zea mays L.) in Europe
}

\author{
Pedro Revilla ${ }^{1 *}$, Mara Lisa Alves ${ }^{2}$, Violeta Andelković ${ }^{3}$, Carlotta Balconi ${ }^{4}$, Isabel Dinis ${ }^{5}$, \\ Pedro Mendes-Moreira ${ }^{5}$, Rita Redaelli ${ }^{4}$, Jose Ignacio Ruiz de Galarreta ${ }^{6}$, \\ Maria Carlota Vaz Patto ${ }^{2}$, Sladana Žilić ${ }^{7}$ and Rosa Ana Malvar ${ }^{1}$
}

${ }^{1}$ Department of Plant Production, Misión Biológica de Galicia (CSIC), Pontevedra, Spain, ${ }^{2}$ Instituto de Tecnologia Química e Biológica António Xavier, Universidade Nova de Lisboa, Oeiras, Portugal, ${ }^{3}$ Department of Genebank, Maize Research Institute Zemun Polje, Belgrade, Serbia, ${ }^{4}$ Council for Agricultural Research and Economics, Research Centre for Cereal and Industrial Crops, Bergamo, Italy, ${ }^{5}$ Instituto Politécnico de Coimbra, Escola Superior Agrária, Coimbra, Portugal, ${ }^{6}$ Department of Plant Production, NEIKER-Basque Institute for Agricultural Research and Development, Basque Research and Technology Alliance (BRTA), Vitoria, Spain, ${ }^{7}$ Department Food Technology and Biochemistry, Maize Research Institute Zemun Polje, Belgrade, Serbia

Maize (Zea mays L.) is one of the major crops of the world for feed, food, and industrial uses. It was originated in Central America and introduced into Europe and other continents after Columbus trips at the end of the $15^{\text {th }}$ century. Due to the large adaptability of maize, farmers have originated a wide variability of genetic resources with wide diversity of adaptation, characteristics, and uses. Nowadays, in Europe, maize is mainly used for feed, but several food specialties were originated during these five centuries of maize history and became traditional food specialties. This review summarizes the state of the art of traditional foodstuffs made with maize in Southern, South-Western and South-Eastern Europe, from an historic evolution to the last research activities that focus on improving sustainability, quality and safety of food production.

Keywords: Zea mays L., European food, flour, food quality, nutritive value

\section{HISTORY}

Since Columbus met maize (Zea mays L.) in Central America in 1,492, this remarkable cereal became one of the main providers of carbohydrates in the humid Spain, Northern Portugal and many other regions throughout Europe. Nowadays, maize continues to be an essential component of the diet, particularly in America and Africa.

When the Spanish conquerors arrived at the Caribbean Islands, maize quickly became of increasing importance as the conquerors approached the mainland (1). Columbus expedition made his first bread out of cassava (Manihot esculenta L.), but maize was more convenient for increasing bread shelf-life. The first mention of maize bread was made by Gonzalo Fernández de Oviedo, who published the History of Indies in 1,526, including a chapter on maize (2). This new crop was called "mahiz" by Oviedo and he frequently referred to it as "pan," which means bread in Spanish.

The first maize varieties used for bread in Europe came from Central America, where maize had been selected by the natives for human consumption $(3,4)$. Around 1,505 there is a reference to maize bread in the Mediterranean area, where the crop is compared to the already established crops in the Balearic Islands; therefore, according to Sauer (1), maize was cultivated for bread in the Mediterranean area at the beginning of the $16^{\text {th }}$ century. However, maize was not immediately adopted by most Europeans as food because they had wheat (Triticum aestivum L.) and other cereals established since ancient times and maize bread was too different from wheat bread to be easily accepted as a substitute. Therefore, maize was only used for making bread in European areas where 
wheat was not easily cultivated and bread makers followed the traditional European method for making wheat bread (1).

Pérez García $(5,6)$ finds some relationship among agricultural crisis and the establishment of maize, as farmers accept a new crop when they need to overcome a deficit that they cannot solve with the traditional crops. In Northwestern Spain, there were several recurrent crises during the $17^{\text {th }}$ century, due to diseases and rapid demographic growth that required new solutions for feeding people. In the coast of Northwestern Spain, maize became a popular crop after 1,630, replacing millet (Panicum miliaceum L.), wheat and rye (Secale cereale L.). In the inner areas, maize was not present at all before 1,630, and it was introduced more slowly than in the coast, following the courses of rivers. The introduction of maize in the $17^{\text {th }}$ century in Northwestern Spain implied some decisive changes in the agricultural and livestock system from 1,630 (7). Maize replaced millet and other cereals at different rates, depending on the location, affecting the technology, the rural economy, and several societal aspects. Maize transformed agricultural landscape and the diet wherever it became a common crop. One of the main changes was the new type of bread that was always in the family table. Actually, maize, like the replaced crops, was mainly used for bread in the coast.

In Portugal, maize was also introduced shortly after Columbus's pioneering voyage in 1,492. Ferrão (8) mentioned that it was first cultivated in Europe on the fields of Seville and was then introduced in the Portuguese Region of Coimbra. The crop fast expanded in the Center and North coast regions of the country and completely transformed rural livelihoods $(9,10)$, having a strong impact at technological (irrigation, fertilizing, livestock production), landscape (terraces, water mills) and social (traditions, religion, language) levels. The impact of maize expansion throughout the country resulted in a strong genetic diversification led by the crop adaptation to diversified microclimates produced by the sequences of mountains and valleys typical of the Center and Northern regions. Traditionally, the Portuguese maize bread, called "broa," was made at home by women, generally once a week. Selection was made in each village for the specific preferences of the local people, which generated variability for composition, shape, size and flavor of local maize bread.

Maize was used to feed the animals and to produce maize bread that, at that time, almost completely replaced the traditional wheat or rye bread. Maize bread has become a fundamental element of the food system and regional culture. Furthermore, together with wine, maize became the currency in which rents were paid to landlords and in which farmers' wealth was measured (11). The North and Center coast regions remain nowadays the most important Portuguese areas of maize farming and traditional maize bread production, following a recipe of millet bread (borona) referred in Portuguese documents dating from the 12th century (12).

Maize introduction into Italy was almost simultaneous to introduction into Spain and Portugal; furthermore, since the first entrance of maize into Europe, subsequent introductions happened from the successive American territories into diverse areas of Europe, particularly in Northern and Eastern Europe. Maize cultivation in South-Eastern Europe, such as Serbia, has a long tradition, more than five centuries, starting in 1,576
(13). According to Edwards and Leng (14) maize landraces in Southeastern Europe are originated from North America, contrary to those from Spanish maize collections, which are derived primarily from Central America. The assumption was made after a natural classification of first collected maize samples in the former Yugoslavia territory. In the second half of $20^{\text {th }}$ century, after the introduction of hybrids, maize collecting missions were organized to collect European landraces. Collection of maize samples was followed by establishment of national genebanks in Spain, Italy, Portugal, former Yugoslavia, Romania and France (15).

\section{MAIZE FOODS IN EUROPE}

\section{Maize Bread}

Bread is a basic food of the Mediterranean diet, wheat being the main cereal used for bakery. However, in South Western Europe, whole meal maize flour is frequently used for ethnic maize leavened bread (named broa in Portugal) production for which the regional maize landraces (normally open pollinated varieties, OPV) are usually preferred (16-18).

The traditional "broa" bread making process consists of mixing more than $50 \%$ sieved whole meal maize flour, with either wheat and/or rye flour, because these cereals have gluten and, therefore, allow making bread with rheological properties similar to those of traditional wheat or rye bread. The recipe for maize bread was similar to that of wheat bread, i.e., included hot water, yeast, salt, and leavened dough from a previous bread (as sourdough). The dough was then baked in a wood-fired oven. Maize bread is an ethnic product highly appreciated for its unique flavor and texture (19). Different types of maize bread can be produced by using different maize varieties and flour blendings $(17,18)$.

Several food technological developments have been applied to the traditional maize bread resulting in a diversification of innovative maize breads. Gluten-free maize bread, obtained by removing completely the rye and /or wheat flour in the traditional flour blending, is demanded by the gluten-intolerant people market and has been accepted in some rural communities even though its sensory quality is peculiar and has special requirements for bread making technology (20). Legume fortified maize bread formulations [by replacement of part of maize flour by legume flour, such as pea (Pisum sativum L.), chickpea (Cicer arietinum L.), fava bean (Vicia fava L.), or lentil (Lens culinaris L.)] were also well accepted by consumers (21). The optimized replacement percentages were those that allowed attaining high protein content (average increase of $21 \%$, reaching $29 \%$ for fava bean, in relation to traditional maize bread) to label these maize breads as nutritiously enriched (21). The influence of different maize varieties (traditional-white, traditional-yellow, hybrid-white, and hybrid-yellow) and legumes on consumer liking and sensory profiling of the fortified maize breads was studied for process optimization. Chickpea flour incorporation yielded the most closely resembling sensory profile to control. These results open new opportunities for the bakery industry to develop new products to fit the growing consumer demand for healthier and high-protein food. In addition to bakery uses, maize flour has been used in different traditional recipes of maize 
porridge flour (with a different degree of milling) or in pastry or sweets $(22,23)$.

Maize became the main "bread grain" in South-Eastern Europe at the beginning of the $19^{\text {th }}$ century and had that primacy until the middle of the $20^{\text {th }}$ century in the former Yugoslavia when, with the agrarian reform of 1,957, high-yielding wheat varieties were introduced into agricultural production. This begun the period of replacing maize, as the main "bread grain", by wheat. In just two decades, maize completely lost its role in the Serbian diet. The first written scientific study on maize as a food was published in 1,904, in Serbia; it was a report on the chemical composition of maize bread prepared in the traditional way: protein $(5.7 \%)$, oil $(2.2 \%)$, starch $(46.2 \%)$, cellulose $(1.9 \%)$, and ash (1.0\%) (24). According to the rules for the quality of grains, milling and bakery products and pasta of the Republic of Serbia Regulations (Official Gazette RS, 56/2018), bread containing at least $60 \%$ of maize flour can be declared as maize bread, while mixed maize bread must contain at least $20 \%$ of maize flour. With the appearance of extended fresh bakery products in Serbia at the beginning of the $21^{\text {st }}$ century, the use of heat-treated maize products such as extruded maize and micronized flakes as a supplement has become popular.

The addition of heat-treated maize flour that has a pronounced ability to bind and retain water increases dough and bread yield, slows down aging and prolongs the use value of bakery products $(25,26)$. However, from the results, thermally treated maize flour could not improve baking quality. Substitution of wheat flour with $20 \%$ of heat-moisture treated maize starch decreased the elasticity of dough and specific volume of loaf, while the crumb containing heat-moisture treated maize starch was harder than the control (27). Due to the absence of a natural network, such as wheat gliadins and glutenins, required for holding the carbon dioxide released during the fermentation process, maize bread cannot reach the spongy texture of wheat bread. According to the results of Simic et al. (28), bread samples with $30 \%$ of maize flour showed a volume reduction of $20 \%$ compared to wheat bread. In addition, cohesiveness, resilience and springiness were reduced from 30 to 42,40 to 53 and 16 to $20 \%$, respectively, for maize mixbread compared to wheat bread. Although zeins, the main storage proteins of maize $(29,30)$, are not able to form viscoelastic fibrils at room temperature as wheat gluten, maize flour is often used as a principal ingredient for different gluten-free foodstuffs, replacing wheat flour. As mentioned above, pure gluten-free maize bread cannot be found in Serbian markets, but gluten-free bread mixtures with the addition of maize flour and/or starch from domestic and foreign producers are sold. Gluten-free bread mixtures usually contain buckwheat (Fagopyrum esculentum L.), millet, rice (Oryza sativa L.), and/or maize flours, and guar or xanthan gums but also coconut (Cocos nucifera L.), tapioca (Manihot esculenta Grantz), amaranth (Amaranthus caudatus L.) and/or quinoa (Chenopodium quinoa L.) flours.

\section{Italian Polenta}

The specific use of maize flour in Italy is for making the traditional dish "polenta," which is very popular in Northern regions. It is a porridge-like dish, generally made by mixing maize flour with salted water through constantly stirring while heating
$(31,32)$. The name "polenta" derives from earlier forms of grain mush made out of barley (Hordeum vulgare L.) known also as "puls" or "pulentum" in Latin) commonly eaten since Roman times. Polenta is traditionally cooked in a large copper pot, named "paiolo," and is traditionally a slowly cooked dish, cooking taking sometimes $1 \mathrm{~h}$ or longer. Recently, instant or precooked polenta has become popular in Italy and in other countries. Polenta can be mixed (generally at the end of cooking or at the time of serving) with various foods such as butter, various cheese types, fish (in particular codfish), porcini mushrooms (Boletus edulis), sausages, or meat. Different kinds of polenta are prepared on the basis of the maize variety and of the type of milling. In fact, polenta is made with either coarsely or finely ground dried yellow, white or red cornmeal, depending both on the area and the desired texture (33).

\section{Western European Specialties: Talo and Gofio}

Besides bread, maize is used in diverse recipes in western regions, "talo" and "gofio" being some of the most distinct specialties developed in Spain. The maize flour cake called "talo" was first produced in the $17^{\text {th }}$ century in Guipúzcoa (Basque Country) as a result of the replacement of wheat and barley by maize, due to soil conditions and high rainfall in that geographical area. The climate in the Basque Country and the rugged terrain made it difficult to grow wheat, so millet and chestnuts (Castanea sativa L.) were grown. After maize introduction, its good adaptation and productivity made that millet practically disappeared, and the local name for millet, "artoa," was used to name the American cereal. Previously, bread was made of millet, chestnuts or a mixture of various flours of rye, barley and spelt, but, in 1,754, Manuel Larramendi in his "Corografía" of Guipuzcoa described the maize flour cake as the main food in the diet of the Basque population.

In this way, the maize flour cake became a substitute for wheat bread for the majority of the rural society and it was made of ground toasted maize, water and salt. Traditionally it was roasted under the ashes of the fire or on a hot metal plate called "taloburni" (talo iron). For breakfast, pieces of maize flour cake soaked in milk were eaten; for lunch, beans with slices of maize flour cake stuffed with jerky and bacon, and, for dinner, leftovers with more maize flour cake or sweet or salty maize-based porridge. They also used oak (Quercus sp.) fruits which were ground and mixed with maize flour (34).

Nowadays the maize flour cake is mainly made from local varieties such as the maize called "txakinarto," grain is harvested when the ear is not yet fully ripe, dried for $24 \mathrm{~h}$ and crushed in stone mills. Several works on agronomic characterizations of local varieties of maize in the Basque Country have been carried out (35-37). Likewise, evaluation trials of flours have been carried out for certain varieties of the Basque Country (38); the most widely used varieties for the production of maize flour cake correspond to varieties with soft and less compact starch. The composition of the flour depends on the degree of extraction-quantity of flour obtained from $100 \mathrm{~kg}$ of maize kernels-so as the degree of extraction increases, the proportion of starch decreases and the content of components of the cereal shells such as minerals, vitamins and fiber increases. Also the 
potential of the Near Infrared Reflectance Spectroscopy (NIRS) to predict the crude protein and starch content in grain and flour were evaluated in maize landraces from the Basque Country (39).

The maize flour cake is eaten wrapping a very fine and fresh "chorizo" or with cheese and even with sweet ingredients such as chocolate. Contrary to the arepa of Colombia and Venezuela or to the tamales or tortillas of Mexico, the maize used in Europe is not nixtamalized (maize soaked and cooked in an alkaline solution) previously; therefore, the paste does not reach a great cohesion and its texture is brittle and sandy, besides being less nutritious. In the elaboration of the maize flour cake, no yeast is added and they are cooked on the griddle, so that flat and rounded sheets of about $20 \mathrm{~cm}$ in diameter are obtained.

"Gofio" is a typical product of the Canary Islands, where maize is mainly used for the consumption of fresh ears in certain traditional foods and as a grain for the preparation of "gofio," which is made with toasted flour and salt. It is usually chosen for breakfast with coffee, milk and bread. It is a product very rich in minerals, such as iron, zinc and magnesium (40). On the other hand, it is a product rich in unsaturated lipids; in particular, it has a lot of Omega 6 and a relatively low caloric content, with about $350 \mathrm{kcal}$ per $100 \mathrm{~g}$ of product. Its fiber content makes it a food with a satiating effect (41).

The presence of maize in the Canary Islands dates back to the end of the 16th century and it is not known whether it was introduced directly from the American continent or whether it first arrived to the Peninsula and was then brought to the Canary Islands (42). Salinas-Moreno et al. (43) describes how maize and barley displaced wheat due to their better adaptation compared to wheat. In this way, the flour of the toasted maize began to be transformed in toasted flour. To make it, the maize was toasted and then milled. It seems that this food has a Berber origin, since it is a traditional food very similar to the flours used by the people of North Africa to complete their diet. Toasted flour has been produced and used as food in the Canary Islands since preHispanic times. Chapter XX of the Spanish Food Register defines "gofio" as the product obtained by roasting flours of wheat, maize or their slightly ground grains, and subsequent crushing (44).

"Gofio" can also be made of tender maize kernels; the whole ear is roasted or shelled and toasted; this particular "Gofio" is called "cochafisco." Without toasting, its flour was used to make bread. The maize "gofio" was usually mixed with other cereals, mainly with barley. It was consumed in the most diverse forms and accompanied by all types of basic foods and typical Canary Island desserts such as "frangollo" and may include raisins (Vitis vinifera L.), almonds (Prunus dulcis Mill), lemon (Citrus limon L.) peel and cinnamon (Cinnamommum verum Schaeff) (45).

The toasted maize flour can be used in many ways in the kitchen. Since ancient times, drinks were prepared soaking the flour in hot water and shaking the blend to prepare a sort of shake (46). Today it is more common to soak the flour in milk and mix it with nuts (Juglans regia L.). It is also used to make different types of broth such as fish or vegetable broths more consistent. Finally, the flour can be also used for making biscuits or cakes (47).

\section{Eastern European Specialties}

Since maize was introduced as a crop in Eastern Europe, various parts of the plant have been used for human and animal consumption (24), medication (48), heating, production of bioethanol and other industrial products $(49,50)$. Traditional Serbian food products made from maize flour, some of which are still prepared today, include maize bread, proja, cicvara, kačamak, komlov, as well as drinks such as brandy komadača and boza. Proja is a traditional unfermented bread made from pure maize flour. Maize flour was added to a bowl of warm water until the mass is thick. A little salt and a little fat was added to the mass also. The mass was shaped and baked in brick oven. Today, unfermented bread is made with the addition of wheat flour, yogurt, sour water, baking powder, various cheeses, cracklings, herbs, different seeds, etc. The recipes of these traditional maize foods have undergone significant changes over time. Today, it is prepared as a specialty in ethnic restaurants throughout Serbia. Kačamak represents densely cooked maize flour in water. It is prepared in different ways depending on the area of Serbia. It can be topped with hot fat, milk, yogurt, and cheese or cream can be added to it. In addition to Kačamak, there are different names for cooked maize such as palenta, puta, maljuga, mamaljiga. Proja and kačamak are mainly made from yellow maize flour rich in carotenoids, primarily lutein and zeaxanthin. Cicvara is mainly prepared from white maize flour. In the boiling mixture of water, milk, cream and strong cheese, maize flour is added. The mass is continuously kneaded for a minimum of $30 \mathrm{~min}$.

\section{ECONOMIC AND SOCIAL RELEVANCE}

Economic and social relevance of maize for food has been studied in Portugal, the European country where maize for food is more relevant. In the last decades, the abandonment of agriculture in general and maize for food, in particular, was noticeable. In fact, between 1998 and 2018, the area and the production of maize in Portugal decreased 27 and 54\%, respectively (51). Nevertheless, maize remains an important crop, currently representing about 2\% of the National Agricultural Output; however, in 1999 that percentage was the double (52). In 2018, 714,000 tons were produced, representing $25 \%$ of total domestic use. Although the human consumption of maize has been slightly increasing in the last years, its production stays around 130,000 tons, representing no more than $5 \%$ of maize total domestic use. The main destination for domestically produced as well as imported maize is the animal feed industry (53).

The same tendency is observed in the two traditional maize bread production regions. In the Northern (North coast) region, between 1998 and 2018, the area and the production of maize were reduced 56 and $52 \%$, respectively (51). In the 1980s and 1990s farmers largely replaced maize for human consumption by maize for animal feed. However, more recently, small farmers have also abandoned livestock farming and the small $(<0.5 \mathrm{ha})$ and unprofitable plots have been left unproductive. In the Center coast region, this trend, although visible, is less pronounced. The area and production of maize diminished 49 and 10\%, 
respectively, in the same period. A progressive decrease in the production and use of traditional varieties also occurred and, at the same time, the traditional knowledge related to the selection of varieties and the production of maize bread was neglected (54). Nowadays some traces of the traditional practices remain but only in household production, for family consumption and direct selling.

Against this scenario, and having in mind that "broa" is a public good, a cultural heritage resulting from empirical evolution over many generations, some collective actions have been developed at local level aiming at the definition of marketing plans able to increase maize bread visibility and use it as a lever for sustainable rural development. Maize for food is a crop that most farmers are familiar with and could be valued when used in regional traditional maize bread production. The traditional varieties have excellent characteristics to be used in bakery, supporting the development of the maize bread value chain.

However, traditional varieties are less productive and more susceptible to climatic stress and diseases and therefore farmers have replaced them by more productive varieties, unless their families bake maize bread for their own consumption. In a case study developed in the Northern region (54) this problem is identified by local actors as one of the most significant threats to the success of an initiative aiming at the development of sustainable maize for food supply chain. It also shows that the main incentive to encourage farmers to produce maize varieties suitable to bake traditional maize bread is a higher price for maize traditional varieties. The case study also indicates that final consumers as well as restaurants seem willing to pay a price premium to reward farmers for the lower yield associated with traditional varieties. At the processing level, local actors raised the question of legislation as one of the major threats for maize bread, arguing that, in Portugal, European rules on food safety are not realistically applied to endogenous food products. A label for traditional maize bread could support local development, similarly to what currently happens with wines and other certified products, not only because it may enhance the maize value chain, but also because it may produce positive externalities in other sectors, namely gastronomy and tourism. The growing interest of some new farmers in endogenous products, as well as the increase in demand, are considered by local actors as opportunities for initiatives aiming at the establishment of a label for local traditional maize bread.

\section{MAIZE FOOD QUALITY AND GENETIC DIVERSITY}

The first maize varieties introduced from America were mainly flint, and they were the base for the subsequent adaptation and selection for diverse uses; actually, local consumers still prefer flint grains of several colors (white, yellow or black), though white grains are normally used for bread, while yellow is used for feed. Traditionally, most people prefer white flint maize for food and particularly for bread because it produces breads more similar to wheat bread. Nevertheless, colored maize contains antioxidants that have interest as functional food $(55,56)$.
Based on our own experience, autochthonous maize populations are growing in importance. Increased interest in populations is derived from the need of reverting the negative consequences of modern breeding for increasing productivity under high inputs, which has reduced the genetic basis and narrowed diversity and, consequently, could favor the loss of beneficial genes for grain quality and stress responses. Traditional maize populations and varieties are a potential source of traits for increasing the nutritional and functional value of grains, since the content of carotenoids, phenolic compounds and antioxidant capacity in maize grain is higher in relation to wheat, oats (Avena sativa L.) or rice. Colored grains, e.g., yellow, orange, purple, blue, or black, are rich in bioactive phytochemicals, i.e., numerous secondary metabolites, and receive more and more interest nowadays.

Maize germplasm in South Western Europe shares origin and history, as well as traditional uses for bread. Revilla et al. (57) assessed agronomic performance and baking quality among autochthonous maize varieties and identified those with the best performance under organic conditions and quality for making bread and traditional maize foods. The selected varieties were Tuy (yellow kernel and medium growing cycle), Sarreaus (yellow kernel and early cycle), Meiro (black kernel and late cycle), and Rebordanes (white kernel and mediumearly cycle). Garzon et al. (58) assessed significant diversity among maize populations from Spain and the United States for dough rheology and gluten-free breadmaking performance, and reported that endosperm type affected bread crumb color, dent maize having higher color parameters and the rheological parameter called "instant recovery speed." These authors also reported that population origin affected the quality parameters flotation index, onset pasting temperature, bread crumb color, hardness and instant recovery speed. Furthermore, growth cycle affected flotation index, crumb color and cohesiveness. Waterbinding capacity, crumb color and hardness were the most discriminative parameters for maize. Though all maize accessions produced bread well differentiated from wheat bread, Garzon et al. (58) concluded that the maize population Andaluz/Daxa was the less distant from wheat for many parameters, and the population Tremesino was the most distant. Moreira et al. (59) found no significant diversity among maize varieties of white, yellow and purple grain for water desorption isotherms; however, white maize flours showed higher average particles size than purple and yellow maize flours.

In Portugal, a unique germplasm has been developed through centuries of adaptation to local environment and food uses, in particular, for the ethnic maize leavened "broa" bread production (60). Because of their use for human consumption, the national maize landraces are in part maintained, and not yet totally replaced by commercial hybrids (17). In the beginning of the $21^{\text {st }}$ century more than 50 traditional maize varieties, still found under cultivation, were collected directly from farmers from a typically maize-based bread-producing traditional region (17). The 50 Portuguese varieties evaluated by Vaz Patto et al. (17) were characterized regarding their flour's quality, and agronomic performance, complemented more recently with a genetic diversity and genetic structure analysis $(18,61)$. Flour 
obtained from each population was used to study flour basic nutritional composition, flour's pasting behavior, and bioactive compounds concentration. Most farmers' populations analyzed showed high levels of protein and fiber, low levels of carotenoids, volatile aldehydes, $\alpha$ and $\delta$-tocopherols, and low breakdown viscosity values (61). In farmers' populations, large variation was found for flour yellowness and total carotenoids, and for the two individual phenolic compounds analyzed p-coumaric acid and ferulic acid (61). This indicates that further improvement to increase the attractiveness of food formulations based on these populations, and specifically for those traits, where variation can still be found, is possible. Accordingly, the Portuguese traditional maize varieties preferred by local consumers for bread, such as Fandango and Pigarro, showed significant higher protein and lower amylose content than hybrids (20).

Historically, Italian maize polenta was obtained from landraces from the different microclimates specific of the several Italian agroecological and agroclimatic areas $(62,63)$. Zeppa et al. (64) reported that quantitative descriptive analysis can be used for sensory description of polenta produced with the simple recipe (maize flour and water), and that the defined lexicon (13 terms: four for odor, three for taste, four for aroma and two for texture) can be used to describe the sensory qualities of polenta produced with 12 Italian maize cultivars. In the first large screening of Italian maize germplasm, 633 landraces were characterized by NIRS for their kernel composition (content of protein, lipid and starch, floating area) and compared to 519 landraces from 20 different countries (65). The carotenoid total content and composition (lutein and zeaxanthin) of the 93 maize landraces of the European Maize Landraces Core Collection (EUMLCC) were also determined. The screening revealed the presence of a wide genetic variability for all traits. The set of Italian landraces comprised in the EUMLCC showed a higher content of total carotenoids as compared to landraces from other countries, and zeaxanthin was more abundant than lutein (on average, 10.46 vs. $5.89 \mathrm{mg} \mathrm{kg}^{-1} \mathrm{dm}$ ). As a result, Italian landraces Nostrano dell'Isola and Marano, characterized by high percentages of protein, lipid and carotenoids and a vitreous texture, were considered interesting in breeding programs and were introduced into high-yielding, modern genotypes, with the aim to be exploited by the food industry. This peculiar carotenoid composition of Italian germplasm, i.e. a larger content of zeaxanthin than lutein (on average, 11.77 vs. $7.13 \mathrm{mg} \mathrm{kg}^{-1}$ $\mathrm{dm}$ ), was confirmed in another study, which reported a detailed characterization of carotenoid fraction in a set of Italian and public inbred lines (66). Cryptoxanthin, being a precursor of zeaxanthin, was also quite abundant $\left(2.47 \mathrm{mg} \mathrm{kg}^{-1} \mathrm{dm}\right)$. In general, the Italian inbreds, selected from traditional maize populations that are still appreciated for their organoleptic properties, are also suitable material for improving nutritional quality of modern maize hybrids for the market of traditional maize-based foods.

Comparison of maize hybrids and autochthonous landraces from Eastern Europe (Serbia and Bosnia and Herzegovina) maintained at the Maize Research Institute Zemun Polje gene bank, differing for grain color, physical properties, grain protein fractions, phenolic compounds, carotenoids content and antioxidant capacity resulted in higher values obtained in landraces (67). Autochthonous varieties have better technological grain quality and performed better than hybrids for dry grain milling and snack food production. Local landraces represent a pool of valuable grain quality traits, as well as a source for grain improvement in commercial hybrids. Ten landraces and inbred lines, with various grain colors were evaluated for total phenolics, flavonoids, anthocyanins, $\beta$-carotene, lutein, free, conjugated, and insoluble bound phenolic acids and antioxidant activity $(68,69)$. Significant variability in phytochemical contents and antioxidant capacity were detected; for example, the content of lutein and zeaxanthin in yellow maize genotypes of the Serbian collection varies from 5.9 to $13.9 \mu \mathrm{g} / \mathrm{g}(68,70)$. Inbred line with orange kernel was superior in $\beta$-carotene content $(2.42 \mathrm{mg} / \mathrm{kg}$ d.m.), while the inbred with light blue kernel has a higher content of total phenolics (5778.2 mg GAE/kg d.m.), flavonoids (337.5 mg $\mathrm{CE} / \mathrm{kg}$ d.m.) and ferulic acid (3274.6 $\mu \mathrm{g} / \mathrm{g}$ d.m.). Although local landraces are dynamic populations, result of natural and human selection, adapted to particular growing conditions, introduced materials may be also very valuable, containing traits not existing in locally-adapted material (71). In the Serbian collection, oil, protein and starch contents were significantly higher $(0.43$, 0.12 , and $0.85 \%$, respectively) in introduced populations than in local landraces. A subset of local and introduced populations from a drought core collection (25 in total), were analyzed for protein, oil, starch and tryptophan contents. Starch and oil contents were 0.84 and $0.39 \%$, respectively, higher in introduced populations. Besides, SSR (Simple Sequence Repeat) primers for opaque2 recessive allele (o2) showed that most accessions (23) had high tryptophan content, and in most of them the recessive o2 allele was found (72). Correlations between proteins, tryptophan and oil make some accessions suitable for simultaneous multi-trait improvement through breeding. These high quality accessions with drought tolerance are good source for nutritional improvement of maize grain.

\section{RESEARCH AND BREEDING FOCUSES}

\section{Nutrition and Health}

Maize food, such as bread, is a healthier alternative to wheat bread due to its lower glycemic index (19). Broa was considered by CNN Travel (73), in October 2019, one of the 50 world's best healthy peasant breads. As a cereal, maize is not a balanced food for humans; though whole grain is a source of dietary fiber and minerals, other vegetables are richer in dietary fiber and minerals contents (74). Besides carbohydrates, maize provides minerals, vitamins and antioxidant compounds, and has high content of potassium, sodium, chlorine and sulfur. Maize protein is poor in lysine and tryptophan but rich in methionine and cysteine.

A second relevant aspect of maize for food is that maize lacks gluten and, thus, it is a convenient food for people suffering from celiac disease, which is an enteropathy caused by ingestion of wheat gliadins and prolamins from rye and barley (75). Those proteins induce an autoimmune response by the activation of IgA antibodies $(76,77)$. Gluten is actually a big problem for celiac patients because even traces of gluten can seriously affect them; therefore, very sensitive methods are required for 
detecting residues and even the most efficient methods for removing gluten cannot guarantee the complete safety of food for celiac patients if wheat or other cereals with gluten are used in the same facilities (78). Torres et al. (79) published a review of bioactivity of available gluten-free food products made with cereals [rice, maize, sorghum (Sorghum bicolor L.), teff (Eragrotis curvula Zucc.) and millets], pseudocereals [buckwheat (Fagopyrum esculentum Moench.), quinoa and amaranth] and other food crops. Unlike wheat gluten, according to numerous studies, maize zeins do not contain toxic and immunogenic peptides. However, hypothetically, maize zeins could be harmful for a very small group of celiac disease patients, especially those that are nonresponsive (80).

Maize can be also a functional food because of pigments and related metabolites with antioxidant activity. Indeed, carotenoid, xanthophyll and anthocyanin have been associated with a reduced risk of degenerative diseases including cancer, cardiovascular disorder and impaired vision $(55,56)$. Orange and yellow maize contain carotenoids, being $\beta$-carotene the carotenoid with the highest pro vitamin A activity (81). The most abundant carotenoids in maize grain are lutein and zeaxanthin, and carotenoid content is regulated mainly by additive effects, which implies that they can be improved by selection (82).

Among cereals, pigmented maize is the most important source of anthocyanins and it can be a substitute for wheat in cookies and crackers both because of the attractive color and the healthy effect. In order to preserve the stability of phenolic compounds and color formation in dark red and blue maize cookies, Žilić et al. (83) added 0.2 and $0.4 \%$ of citric acid to the mass, which contained colored maize flour, refined palm oil, sucrose powder, nonfat dry milk, sodium bicarbonate and water. Blue popping maize cookies with citric acid had $\mathrm{pH}$ values of 4.41 and pink color. Lightness (CIE L*) and redness (CIE a*) of blue popping maize cookies with citric acid were increased compared to colors of their corresponding doughs. The results of these authors show that citric acid had a stabilizing effect and improved accessibility of the anthocyanins. The content of anthocyanins in the blue popping maize cookies with $0.2 \%$ of citric acid increased by 1.11 -fold in the flour. Reduced $\mathrm{pH}$ with citric acid at low temperatures restricted Maillard reaction and browning during baking of maize cookies. At pH 7.39 to 7.85 in yellow, red and blue maize cookies, Kocadagli et al. (84) found a high content of 3-deoxyglucosone, as well as higher sucrose hydrolysis. However, these authors state that colored maize flour could be the source of natural dietary antiglycation agents due to good abilities of their phenolic compounds to trap $\mathrm{C}_{2}, \mathrm{C}_{3}$ and $\mathrm{C}_{4} \alpha$-dicarbonyl compounds. The effect of maize flour and baking conditions on the formation of Maillard reaction products in cookies was studied also by Žilić et al. (85). Red popping flour with the lowest content of free asparagine of $189.7 \mathrm{mg} / \mathrm{kg}$, generates the least acrylamide in the cookies in relation to white, yellow and blue maize flours. The results also show that the acrylamide content after 13-min baking was higher in cookies made of hulless oat, durum wheat and rye flours than those made of maize flours.

The development of new pigmented maize genotypes rich in bioactive (antioxidant) compounds could be a good tool to increase the functional properties and healthy power of the human diet. Italian local varieties from the CREA Genebank in Bergamo $(86,87)$ were crossed with germplasm from Bolivia (purple "Morado"-type) and from Mexico (blue "Azul"-type) and selected to obtain new pigmented maize genotypes, in the frame of the International Cooperation Project P.S.G.O. Km 0 Bolivia (2018-2021) (88). The materials developed in this research could be valorized also considering that, as reported by Rodríguez et al. (16), the selection for red kernel color intensity in maize, yields high levels of anthocyanins that vary from black maize kernels to white grains from the same variety and produces higher antioxidant activity in the kernels with darker color. The development and study of maize cultivars rich in anthocyanins for colored polenta as new functional food were also reported in literature $(89,90)$.

Pigmented maize can be a beneficial food for humans due to the presence of numerous antioxidant substances and biofunctional compounds. These compounds are present in the whole kernel in different concentrations depending on the pigmented maize genotype (91). The results reported by Lago et al. (89) showed that anthocyanins content of maize flour decrease of about $22 \%$ in the anthocyanins content of polenta probably due to the cooking process, as previously highlighted in maize by Salinas-Moreno et al. (43) and in fruits and vegetables by Jones (92). Nevertheless, based on previous reports, despite the decrease due to cooking, the colored polenta retained appreciable amounts of anthocyanins and good relative levels of antioxidant activity, and can be considered a functional food. Additionally, the taste perception by consumers revealed no differences between colored and uncolored polenta (89), suggesting that selection of new maize polenta varieties, rich in anthocyanin pigments, could be an acceptable option for consumers and a valuable tool to increase the antioxidant power in human diet.

The significant maize variability for grain composition is source of favorable alleles for improvement of grain micronutrient content by conventional breeding or by biotechnology, for better utilization in human diet. Therewith, colored grains, rich in anthocyanins, have various health benefits, preventing diseases associated with oxidative stress. In the investigation of composition and content of anthocyanins in the grain of blue popping maize, deep purple maize, purple wheat, and black soybean (Glycine max L.), the following results were obtained: deep purple maize had the highest content of total anthocyanins (4988.9 mg cyanidin 3-glucoside equivalent/kg d.m.), with dominance of the glucosidic forms; ten anthocyanins were identified in blue popping maize and the acylated forms of anthocyanins were dominant. The study also highlighted colored maize as one the best sources of anthocyanins (93).

Currently, given the specific requirements of today's consumers in Serbia, wholegrain flour of specific maize genotypes, such as open pollinated varieties, rich primarily in bioactive compounds, is added to the wheat flour in order to increase the functional value of bread. Replacing 30\% of wheat flour with wholegrain blue and dark-red maize flour increased phenolic compounds content in bread and its color (28). The same authors reported that the content of total phenolic compounds and ferulic acid was from 2.8 to 4.2-fold and from 22 to 25 -fold, respectively, higher in maize mix-breads than 
in wheat bread. Despite thermal degradation, the content of total anthocyanins in crumb of blue and dark-red maize mixbreads was relatively high and amounted to $142.3 \mathrm{mg}$ cyanidin 3 -glucoside equivalent/kg and $84.4 \mathrm{mg}$ cyanidin 3-glucoside equivalent $/ \mathrm{kg}$, respectively, which is a considerable enrichment of wheat bread in terms of its functionality and health effects.

Nutritive value of maize bread can be improved by adding ingredients, for example, Collar et al. $(94,95)$ reported that blended maize matrices with added resistant starch and wheat flour modified textural profile, crumb grain features and firming kinetics, and free polyphenol pattern of breads compared to the maize bread alone. All maize breads had high-fiber, and enriched bread at large provides enough resistant starch to positively affect postprandial glucose and insulin levels and enhance health.

Comparing to other cereals, maize contains a high level of soluble phenolic compounds, in particular of hydroxycinnamic acids such as the free ferulic and p-coumaric acids (96). These phytochemicals are considered health promoting components, with anti-bacterial, anti-aging, anti-carcinogenic, neuroprotective, cardiovascular and anti-diabetic properties (96). Interestingly, the major soluble phenolic compounds present in maize flour, hydroxycinnamic acid amides, particularly dicoumaroyl spermidine, coumaroyl feruloyl putrescine and diferuloyl putrescine, resist to maize flour fermentation and baking process. Furthermore, using traditional processing conditions, the bread content in free ferulic and p-coumaric acids increased more than 3-fold compared to flour contents, meaning that the bioaccessibility of maize phenolic compounds could be improved, substantiating the potential health benefits of broa (97).

In order to implement the scarce references about phenolic compounds in yellow maize, a simple and repeatable method for spectrophotometric analysis of soluble phenolics content (SPC) in maize flour was used, and a first screening of 81 genotypes, comprising inbred lines, landraces and F1 seeds, was carried out (98).

Total antioxidant capacity (TAC) represents an important tool to estimate the potential pro-healthy value of a raw material. TAC can be determined by different enzymatic methods (99101). A chemometric model for the prediction of TAC in maize flours by NIRS was assessed in a set of 391 samples, comprising Italian and public inbred lines, F1 seeds, commercial hybrids and traditional varieties, using ABTS direct assay as reference value (102). The good stability of the regression coefficients allowed developing both global and specific predictive models for this trait, demonstrating that NIR spectroscopy could be applied efficiently to the screening of the genotypes.

Maize is widely considered a "key" raw material in glutenfree (GF) formulations $(103,104)$, as maize starch is a "viscosity-builder" through the gelatinization and retrogradation phenomena that occur during the processing of GF foods (105). The increasing request for maize for food production stimulated the identification of Italian genotypes having specific qualitative parameters, including kernel hardness and peculiar starch properties, both strategic for food processing (106).

Besides diversity available among natural genetic resources, there are several natural mutants that can increase the genetic resources for maize breeding, for example, Revilla et al. (107) evaluated the bread potential of high amylopectin (waxy1) and high-quality protein (opaque2) maize mutants for bakery and found that while $o 2$ had no significant mean effects, $w \times 1$ decreased flotation, onset pasting temperature, maximum and final viscosity, trough, breakdown, total set back, area under the apparent viscosity curve, hardness, chewiness and instant recovery speed, and increased water binding capacity, reddish crumb color, retarded recovery elasticity and cohesiveness.

\section{Safety}

One of the major safety problems of cereals is the contamination with mycotoxins, as the European Mycotoxin Awareness Network and FAO recognize (108, 109). Mycotoxin contamination of maize grain is a global threat to safety both for human food and animal feed (110). Mycotoxins are secondary metabolites produced by toxigenic fungi, which may be toxic or have other debilitating effects on living organisms (111). The chronic exposure to mycotoxins represents a critical factor for human health (112).

Mycotoxins are fungal metabolites that, when ingested, inhaled or absorbed through the skin, cause low performance, sickness or death in man or animals. They are produced by fungi of genera such as Fusarium, Aspergillus or Penicillium. There are more than 300 mycotoxins with diverse chemical, biological and toxicological characteristics that can be produced in many crops and derived products. Mycotoxins and their derivatives have diverse toxic potential, depending on the type of mycotoxin, concentration, length of exposure and characteristic of the exposed individual, and damage can be especially important on liver, kidneys, and immune, endocrine or nervous systems (113). They can be mutagenic and carcinogenic; potential carcinogenic risk for some mycotoxins has been rated by the International Agency for Research on Cancer (IARC). Therefore, legislation to limit the amount of some mycotoxins has been implemented in many parts of the world to minimize human health risk. Accordingly, several international institutions have made recommendations and stablish concentration limits (114), which are particularly strict in the European Union (115). The incidence and severity of mycotoxin contamination in Italian maize cultivated area, mostly caused by Fusarium verticilliodes (fumonisins) and by Aspergillus flavus (aflatoxins), is highly dependent on genotype, agronomic practices, environmental conditions, biotic and abiotic stresses (116-118).

Combination of vegetal products can be useful for mitigating mycotoxin damage. Fumonisins can be controlled with isothiocyanates that are natural compounds from plants of the Brassicaceae family, produced by enzymatic conversion of glucosinolates and decrease Fusarium mycotoxigenic strains by reducing mycelium size (119). Isothiocyanates also reduce fumonisins levels naturally produced in bread by Gibberella moniliformis and bioaccessibility and bioavailability of fumonisin (120).

Fermentation and baking of dough also cause important mycotoxin losses $(121,122)$; therefore, bakery improves the safety of maize foods. However, this process is the objective of several researches. Krska et al. (123) carried out the project MyToolBox for developing novel interventions aimed at achieving a significant reduction in crop losses due to mycotoxin 
contamination. Among the diverse focus of that project, they also studied the effects of baking on mycotoxins at an industrial scale. Lino et al. (124) analyzed breads from Northern Portugal and 73 $\%$ of samples had fumonisin levels above the limit established by the European Union, though they were not considered a health hazard because of the low proportion of bread in the diet. Similarly, breads from different regions of Portugal have diverse concentrations of ochratoxin A depending on the characteristics of the bread and the regions $(125,126)$. Ochratoxin A (OTA) is a secondary fungal metabolite produced by Aspergillus ochraceus, A. carbonarius, A. niger and by Penicillium verrucosum that can be present in most bread samples of the Atlantic coast (127).

Maize kernels can be contaminated with mycotoxins mainly at the pre-harvest stage (128), and infestation is promoted by high temperature and insect damage (129). Cao et al. (130) investigated environmental factors related to fungal infection and fumonisin accumulation during the development and drying of maize and reported that Fusarium verticillioides was the most prevalent species. They also found that temperature and moisture conditions during the first 80 days after silking favored natural kernel infection by $F$. verticillioides. Fumonisin was found in kernels 20 days after silking, though fumonisin accumulation was not above levels acceptable in the EU until physiological maturity is achieved.

One of the factors involved in increasing fumonisin was insect damage, particularly Sitotroga cerealella. The main insect pests of maize in Southern Europe are the corn borers Sesamia nonagrioides and Ostrinia nubilalis (131). Butrón et al. (131) evaluated corn borer damage in northwestern Spain and found that the Italian late white variety Bianco Perla was the most appropriate to obtain high yield along with reduced stem damage by $S$. nonagrioides and reduced risk of fumonisin contamination, along with the early Spanish varieties EPS12(T)C3 and Rebordanes. Other mycotoxins are not detected in maize bread; for example, Herrera et al. (132) developed a straightforward analytical method to determine the mycotoxin moniliformin in cereal-based foods and reported that moniliformin was not detected in bread samples (133).

The Italian maize germplasm maintained at the CREA Genebank in Bergamo contains nearly 500 inbred lines and 600 local varieties (landraces) gathered in different regions in the 50's, when the cultivation of hybrids begun to was replace landraces; so, it represents an interesting starting point for searching genotypes resistant to fungal pathogens useful to reduce mycotoxin contamination $(87,118)$. The screening through field artificial inoculation of inbred lines (118) and traditional varieties (87) highlighted that there are some interesting maize Italian germplasm sources of resistance to mycotoxin accumulation useful to support grain quality safety. On the other hand, 240 inbreds from the Spanish collection, of different origins, were evaluated in the field for 2 years for grain resistance to Fusarium verticilloides and fumonisin with artificial inoculation. Sixty-one inbreds were found to have the highest levels of resistance to both across years (134). Inbreds differing in kernel color, use, kernel type and heterotic group were all represented in this group of the best inbreds. Many of these inbreds are being used in breeding programs to improve F. verticilloides and fumonisin resistance (134).
Research reported in literature indicated that pigmented maize kernels could express possible plant defense functions against biotic (fungal pathogens and pests) and abiotic (drought) stresses because of the high antioxidant power of components determining kernel pigmentation (135-138). A recent study highlighted the role of phlobaphenes (insoluble phenolic compounds conferring a red-brown pigmentation to kernel pericarp) in modifying pericarp thickness and reducing fumonisin mycotoxins accumulation (139). The traditional Italian cultivar Nero Spinoso from the Camonica Valley had a very high level of phlobaphenes and a pericarp layer thickness significantly higher than the colorless control (140). In this perspective, maize pigmented genotypes developed for their content in specific bioactive phytochemical compounds, could be also suitable to be introduced into advanced breeding programs aimed to enhance and valorize biodiversity potential on resistance to mycotoxigenic pathogens and on grain quality and safety improvement. In the evaluation of the inbred collection from the MBG germplasm bank, white corn inbreds had higher levels of fumonisin than yellow ones, but it was still possible to find white inbreds with comparable resistance to fumonisin accumulation to that of the most resistant yellow inbreds (134).

Other health hazards include metals, such as Aluminum, whose toxicity restricts cultivation of crop plants and causes substantial losses of production in areas with acidic soils. GarciaOliveira et al. (141) stated that maize is relatively less sensitive to Aluminum contamination. Other metals are not a major problem in the areas where maize is used for bread in Europe.

\section{Quality}

The first Europeans accepted maize as food when they were hungry, because, in the 17th century, maize was considered nurture for vulgar people (142). Quality parameters have not been specifically defined for maize bread; though, FAO (143) classified five quality grades, based on grain density, proportion of whole grains, damaged grains, and grain color. High quality implies high test weight, low proportion of broken grains and foreign material and color uniformity. Moreira et al. (59) developed a model to predict flour color involving color parameters of the different particle size fractions. Flint maize is hard and produces large particle size that made flour rougher and reduce reflectance (144). Grain density is important for dry milling but reduces yield (145).

In what concerns the technological ability of Portuguese maize for maize bread production (61) (breadability), several parameters related to kernel composition, flour pasting behavior and flour particle size have been previously identified as crucial $(20,146)$. Brites et al. (20), through a sensory analysis on maize bread carried out by a trained panel with different maize varieties, identified a preference for maize bread produced using open-pollinated populations, due to texture, taste, and aroma, as opposed to maize bread produced using commercial hybrid maize varieties. Furthermore, the flour from openpollinated populations, besides having better quality maize bread, had higher values of protein, lower values of amylose, and lower viscosities (maximum, minimum, final, and breakdown viscosities) (20). More recently, technological processing quality differences between the higher-yielding dent hybrids and the 
hard endosperm Portuguese open-pollinated populations have shown that the maize bread produced with the dent hybrid varieties had higher specific volume; however, a sensory analysis showed a preference for the maize bread made using Portuguese open-pollinated populations due to better mouthfeel flavor and texture (146). The higher protein contents detected on the varieties with higher breadability, can probably induce increased amounts of water absorption ratio by the flour enlarging bread moisture. In fact, the crumb moisture was identified (146) as a relevant attribute for consumer acceptability of maize bread. As maize lacks gluten, obtaining the spongy texture in bread made with maize is a technological challenge because maize lacks the natural network required for holding the carbon dioxide released during fermentation (147). Brites et al. (20) also evaluated different milling processes (attending to formulation and processing variables) on quality attributes of maize bread and concluded that grinding in a water mill takes more time, had lower ash content and higher maximum, minimum and final viscosities than in electrical mill. Traditional processing allows damage by insects or fungi that are dangerous for human health (148). Though the effect of most environmental factors, such as plant biodiversity or pollination quality, is poorly known, bread quality depends on environmental and genotypic factors such as grain weight, moisture, uniformity, density, and lack of physical, disease or pest damages (149).

As fermented food, sugars are converted into organic acids in maize bread, affecting organoleptic, rheological properties and self-stability $(150,151)$. Other effects of fermentation are increase of viscosity and crumb firmness (152) as well as other physical and chemical modifications. Pico et al. (153) found that fermentation maintained stable levels of hexanal, hexanoic acid, benzaldehyde, benzyl alcohol, furfural and furfuryl alcohol but increased other volatile compounds. Conversely, baking evaporated 2,3-butanedione, 1-propanol, 2-methyl-1-propanol, 3/2-methyl-1-butanol and ethyl octanoate and increased other volatile compounds. The main volatile compounds in dough were the alcohols from fermentation, 2,3-butanedione, acetoin, acetic acid, isobutyric acid and ethyl octanoate, and, in crumb, also hexanal, 1-octen-3-ol and nonanal were important contributors.

Conservation of quality is another important factor for perishable foodstuff. Revilla et al. (154) assessed the influence of growing and storage conditions on bakery quality of maize for bread under organic agriculture. They studied the genotypic and environmental effects on grain quality for human consumption using traditional grain processing methods. Genotypic effects were more important for grain quality; meanwhile environment was more important for grain yield and pericarp damage. Warmair drying increased grain quality and medium-term storage increased grain quality but reduced germination percentage. The main factors for optimizing quality were appropriate growth cycle and proper harvest time. Furthermore, quality and agronomic performance can be managed independently of each other except for the negative correlation between moisture and milling test.

Bread attributes depend also on physical characteristics, such as flour particle size (155). De la Hera et al. (155) found that finer-particle-size flours lowered dough development during fermentation in all cases, flours with compact particles had higher specific bread volume and greater particle size, dough with more water gave breads with higher specific volume, especially in compact flours. They concluded that flours with coarser particle size are the most suitable for gluten-free maize bread. Other methods of improving quality include mixing flours from different cereals; actually maize and rice can be used for glutenfree food because both cereals lack gluten. Mancebo et al. (156) studied quality of mixtures of gluten-free flours and found that incorporating starch increased bread specific volume and cell density, but not color, and quality was worse compared to wheat bread.

\section{Niacin Availability}

Maize content in niacin is not naturally available for humans without adequate processing, and lack of niacin causes pellagra. The introduction of maize into European diet was associated with specific nutrient deficiencies such as pellagra, a disease that was unknown in Europe due to the nutritional value of the European cereals (157). Pellagra is the result of a diet that does not contain niacin (vitamin B3) as well as tryptophan, its precursor. Pellagra was common in some regions of Europe, and still is today in sub-Saharan Africa, in people who mostly subsist on maize. Symptoms of pellagra include inflamed skin, diarrhea, dementia, and sores in the mouth. Anorexia and malabsorptive diarrhea lead to a state of malnutrition and cachexia and, without treatment, may result in death (158). In America, this deficiency was solved with a process called nixtamalization, which is an alkaline solution treatment which corrects the niacin deficiency, and was a common practice in Native American cultures. Žilić et al. (70) indicated that $8-65 \%$ of total niacin was liberated from a chemical linkage by alkaline treatment. Tryptophan-rich maize had a lower content of total niacin $(99.44 \mathrm{mg} / \mathrm{kg})$ and higher content of available niacin $(42.61 \mathrm{mg} / \mathrm{kg})$ than regular maize. The earliest description of pellagra was made by the Spanish physician Don Gaspar Casal in 1763 (159). Pellagra spread through Europe from Spain to Italy, France, central Europe, Romania, Turkey, Greece and parts of southern Russia (159). For over 200 years, between the 18th and the 20th centuries, pellagra was endemic in those parts of Italy that depended on maize as a staple crop (157). Pellagra affected over 100,000 people in Italy by the 1880 s, when it was attributed to the extensive consumption of maize as "polenta" (160). During the late 19th century, hypotheses emerged that maize either carried a toxic substance or was a carrier of disease since pellagra outbreaks occurred in regions where maize was a dominant food crop. Later, researchers found that pellagra could be prevented by modifying processing techniques or by including animal and leguminous proteins or a small amount of brewer's yeast.

\section{Breeding Programs}

The market sector of maize for bread is limited compared to markets for other major uses of maize. Consequently, few specific breeding programs to improve maize varieties for bread have been developed in Europe. The most outstanding project is the VASO project in Portugal that started in 1984 by Silas Pêgo and is an on-farm participatory maize breeding (PPB) project at the Portuguese Sousa Valley region $(9,10,18)$. The breeding program focuses on yield, bread making quality and 
the ability for polycropping systems. This breeding program was applied to local varieties as Amiúdo or Pigarro and to a synthetic variety named Fandango that represents a transversal project between on-station and on-farm programs. The project carried out with Pigarro (161) includes two selection programs i) phenotypic recurrent selection and $S_{2}$-lines recurrent selection (named breeders selection) and ii) stratified mass selection with two-parental control in three sequential steps (two in the field and a third one at the storage facilities) (named farmers selection) (162). A joint molecular and agronomic comparative study that took place under this PPB program using Pigarro (162), indicate that for both farmers and breeders' selection methods, genetic diversity was maintained, even with the more intensive breeder's selection, suggesting that further response to selection can be expected. However, yield increase was only detected during farmer selection. Indeed, farmers' selection was more effective in increasing fasciation-related traits and cob weight, what might have contributed for the yield increase. Ear fasciation is particularly important for farmers, to maintain a certain level of diversity, toward a long-term gain in ear diameters, kernelrow numbers, medulla and rachis dimensions (17). The breeders' selection on the other hand, was more effective in achieving crop uniformity, plant and ear height reduction and greater resistance to stalk lodging (162). So, although both selection approaches achieved phenotypic modifications though preserving genetic diversity, only the farmers' selection resulted in a yield increase and, as it is a cheaper methodology, technically more accessible to farmers, this would be the choice for future PPB.

Besides comparing the two selection approaches applied in the Portuguese maize PPB program, the impact of the breeding activities on the maize populations' agronomic performance improvement has been also measured in four out of the several maize populations in the program $(161,163,164)$. Furthermore, the temporal changes in genetic diversity were evaluated for three of those populations $(163,165)$. Overall, participatory breeding methodologies were partially effective in improving the agronomic performance of the maize populations, while maintaining high molecular diversity in these populations. The quality traits evolved randomly across the breeding program (163). This observation warns for the need to develop selection tools for characteristics that cannot be visually selected by farmers. Indeed, a more detailed evaluation of the effect of breeding programs on quality aspects is needed since the quality of these genetic resources for maize bread production is a decisive aspect for the on-farm maintenance of these historical populations and for their present market addedvalue recognition $(20,60)$. VASO project updates have been able to include transdisciplinary and multifactor approach that includes farmers and rural development associations, millers, bakers, academia, municipalities and consumers defining targets in the network filling the gaps from the seed to fork; searching economic models that have to be created and adapted. VASO project seeks to improve germplasm and its use so that varieties are attractive to consumers, the processing industry and farmers, responding to public concerns related to health and the environment, increasing the sustainability of agricultural systems and contributing to the short chain and well-being
TABLE 1 | Research lines about traditional maize food in Europe and references for each line.

\begin{tabular}{|c|c|c|}
\hline Type & References & \\
\hline \multirow[t]{6}{*}{ Bread } & Making process & $(17-19,24)$ \\
\hline & Food technologies & $\begin{array}{c}(20-23,26- \\
30,58,59,94-97 \\
107,123,124,146)\end{array}$ \\
\hline & Genetic diversity & $\begin{array}{c}(16-18,20,57-61,98 \\
107,125,126,134)\end{array}$ \\
\hline & Nutrition and health & $\begin{array}{c}(16,20,55,56,61,73 \\
74,79,80,96- \\
98,123-126,134 \\
169,170)\end{array}$ \\
\hline & Quality & $\begin{array}{c}(20,59,60,146,148 \\
149,153,154,158)\end{array}$ \\
\hline & Breeding & $\begin{array}{c}(9,10,16,18,161- \\
164,167-175)\end{array}$ \\
\hline \multirow[t]{4}{*}{ Italian polenta } & Making process & $(31,32)$ \\
\hline & Food technologies & $(33,64,66)$ \\
\hline & Genetic diversity & $(33,62-66,89,90,140)$ \\
\hline & Nutrition and health & $\begin{array}{c}(65,66,88-90,93 \\
116-118,139)\end{array}$ \\
\hline \multirow[t]{4}{*}{ Western specialties Talo and Gofio } & Making process & $(34,40,44)$ \\
\hline & Food technologies & $(38,45-47)$ \\
\hline & Genetic diversity & $(35-37)$ \\
\hline & Nutrition and health & $(41)$ \\
\hline \multirow[t]{3}{*}{ Eastern specialties and cookies } & Food technologies & $(67,83)$ \\
\hline & Genetic diversity & $(67-71)$ \\
\hline & Nutrition and health & $(67-71,83,85)$ \\
\hline
\end{tabular}

of farmers, for which a greater involvement of national and local actors (GO) are needed (54). It is also important to stress that VASO paved the way to promote use and valorization competitions such as the "Best ear of Sousa Valley" in which development of genetic resources and pedagogical tools based on statistical tools were elaborated and made available to farmers (166). Another breeding program was carried out in the Basque Country, Spain, by Ruiz de Galarreta from the "Instituto Vasco de Investigación y Desarrollo Agrario" NEIKER in collaboration with the Federation for Organic Agriculture of the Basque Country (North of Spain) for improving the talo (a special type of maize bread) quality of the variety Donostia (38).

Breeding maize for bread can also focus in a specific target, such as improving the value as functional food by increasing the antioxidant activity; for example, Rodríguez et al. (16) evaluated a selection program for color intensity on antioxidant capacity in maize. They reported that pigment content was directly related to antioxidant capacity in maize kernels and also to the hydrophilic fraction, while the lipophilic fraction was not related to antioxidant capacity and visual selection for kernel color increased anthocyanin content. They also concluded that the traditional method for making maize bread out of whole maize flour has not significant effects on pigment content or antioxidant capacity. Another breeding objective is grain health, particularly, genetic variability for mycotoxin contamination has been reported in maize, and there are selection programs 
under way $(167,168)$. Maize breeding has primarily focused on increasing stability and grain yield potential, under abiotic and biotic stresses (169). In the last decade, however, much effort has been made in evaluating and using the diversity of maize also on the improvement of animal feed and human nutrition (169). Currently, maize breeding efforts for improved chemical composition is being extended beyond the traditional targets of starch, oil, and protein to include components such as vitamins, and antioxidant secondary metabolites with considerable consequences for human health (170). By using marker-assisted selection, a few nutritional trait-associated genes or quantitative trait loci (QTLs) for maize protein quality, oil content and provitamin A levels have been introgressed into elite maize lines for their quality improvement (170).

The difficulty of tracking particular quality compounds using traditional breeding methodologies and the importance these compounds have on consumers' food acceptance, demonstrated the need of using other approaches such as marker-assisted selection (MAS) to breed for such traits. Taking advantage of a collection of maize inbred lines in which a considerable amount of the unexplored Portuguese maize germplasm is present, several genome wide association companion studies took place, to develop more efficient breeding tools to support the improvement of the difficult-to-handle complex organoleptic, nutritional and processing quality traits (171-173). These studies identified 64 genomic regions associated with 15 different volatiles (173), 57 associated with 11 different traits affecting maize kernel composition (protein, fiber, fat, and starch content) and flour breadability (starch pasting properties and flour's mean particle size) (171) and 67 associated with color and antioxidant-related traits (carotenoids, tocopherols, and phenolic compounds) (172). The strongest single nucleotide polymorphism (SNP)-trait associations and the SNP alleles with larger effect sizes were set as priority for future validation studies. The validation needed before routine use on breeding may be attained by sequencing the associated regions in an independent germplasm such as the maize populations, which are in fact the materials typically used for the production of maize bread.

Improving maize grain for increasing provitamin $\mathrm{A}$ and vitamin $\mathrm{E}$ contents, e.g., $\beta$-carotene and $\alpha$-tocopherol, as the most important bioavailable compounds for humans, is a significant issue nowadays. Besides increase of single nutrient content, simultaneous breeding for multinutritional traits have numerous beneficial effects. In the study Andelković et al. (174) micronutrient content in three colored grain populations, five inbred lines and their crosses were evaluated. Population with dark orange grain had high content of both, $\beta$-carotene $(26.9 \mu \mathrm{g} / \mathrm{g} \mathrm{d.m}$.) and $\alpha$-tocopherol $(27.2 \mu \mathrm{g} / \mathrm{g}$ d.m.), and could be used as a good source for multinutrient biofortification. Development of maize genotypes enhanced with micronutrients could be achieved by development of inbred lines or creation of synthetic populations, depending on available genetic resources, potential utilization, and endusers needs.
New breeding techniques (NBTs), such as genetic transformation, can be used for breeding specific aspects of maize bread; Grosset et al. (175) reported that the introduction of a gene coding for a barley CMd protein into immature maize kernels by micro-projectile bombardment was successful as the gene was expressed in the outermost cell layers of maize endosperm in both a tissue-specific and a developmentally determined manner.

\section{CONCLUSIONS}

Based on the large published literature and wide variety of research lines (Table 1), in order to fulfill social demands, current maize research and breeding should focus on supporting sustainable production of healthy food with high quality and safety. As maize is a major crop with a large potential of breeding and adaptation, the main objectives of research and breeding include releasing varieties with adaptation to local conditions and high added value given by quality parameters and health interests, such as large antioxidant capacity, resistance to micotoxin contamination, or quality gluten-free products. Food safety is also a concern due to the increase of contamination and the reduction of plant biodiversity in agricultural fields and the surrounding natural areas. Actually, maize has outstanding ability of bioaccumulating heavy metals (i.e., $\mathrm{Cd}$ and $\mathrm{Zn}$ ), and has been proposed as natural decontaminant from heavy metals $(176,177)$, but this ability could hinder food safety.

Therefore, breeding efforts to develop maize varieties for making bread still require establishing clear criteria for measuring quality of maize kernel, developing sustainable agricultural and post-harvest management practices and advanced breeding materials to minimize health risks caused by maize grain mycotoxin contamination, and exhaustive characterization of nutritional profile of maize kernel to determine the potentiality of maize bread as functional food.

\section{AUTHOR CONTRIBUTIONS}

PR conceptualization and redaction of Spanish sections. MA, ID, PMM, and MCVP redaction of Portuguese sections. VA and SŽ redaction of Serbian sections. CB and RR redaction of Italian sections. JG redaction of Spanish sections. RM structuration and organization. All authors have read and agreed to the published version of the manuscript.

\section{FUNDING}

This research was funded by Spanish Ministerio de Innovación y Universidades (MCIU), the Agencia Estatal de Investigación (AEI) and the European Fund for Regional Development (FEDER), UE (project code PID2019-108127RB-I00), the Xunta de Galicia-Spain (project code IN607A 2021/03), and FCT, Portugal (Research Unit UID/04551/2020). 


\section{REFERENCES}

1. Sauer CO. The Early Spanish Main. California, U.S.A: University of California Press, Berkeley and Los Angeles (1966).

2. Finan JJ. Maize in the Great Herbals. Waltham, Mass., U.S.A.: Chronica Botanica Company (1950).

3. Revilla P, Soengas P, Malvar RA, Cartea ME, Ordás A. Isozyme variation and Historical relationships among the maize races of Spain. Maydica. (1998) 43:175-82.

4. Revilla P, Soengas P, Cartea ME, Malvar RA, Ordás A. Isozyme variability among European maize populations and the introduction of maize in Europe. Maydica. (2003) 48:141-52. Available online at: http://hdl.handle. net/10261/32960

5. Pérez García JM. Aproximación al estudio de la penetración del maíz en Galicia. En La historia social en sus fuentes de protocolos. Spain, Univ. Santiago de Compostela (1978).

6. Pérez García JM. O millo en Galicia: un estado da cuestion. Rev Galega de Estudios Agrarios 7/8. (1982) 87-104.

7. Saavedra P. Corn in the agrarian system and food in Galicia, XVII-XIX centuries. Obradoiro de Historia Moderna. (2018) 27:49.

8. Ferrão JEM. A aventura das plantas e os descobrimentos portugueses. Programa Nacional de Edições Comemorativas dos Descobrimentos Portugueses, Portugal (1992).

9. Pêgo SE, Antunes MP. Resistance or tolerance? Philosophy, may be the answer. In: Proceedings of the XIX - Conference of the International Working Group on Ostrinia. Guimarães Portugal, 30th August-5th September (1997).

10. Moreira PMRM. Participatory maize breeding in Portugal. A case study Acta Agron Hung. (2006) 54:431. doi: 10.1556/AAgr.54.2006.4.6

11. Caldas EA. Agricultura Portuguesa através dos Tempos. Instituto Nacional de Investigação Científica, Lisboa, Portugal (1991).

12. Rocha J, Brás A, Trigueiros J, Malcata X. Pão de Milho: Caracterização do Produto Tradicional e Melhoramento Tecnológico, Universidade Católica Portuguesa, Escola Superior de Biotecnologia, Porto, Portugal (2003).

13. Andelković V, Ignjatović-Micić D. Maize genetic resources-science and benefits. Zemun Polje', Serbia: Serbian Genetic Society and Maize Research Institute, ISBN 978-86-87109-07-0 (SGS) (2012).

14. Edwards RJ, Leng ER. Classification of some indigenous maize collections from southern and southestern Europe. Euphytica. (1965) 14:1619. doi: 10.1007/BF00038982

15. Gouesnard B, Dillard J, Bertin P, Charcosset A. European maize landraces. Genetic diversity, core collection definition and methodology of use Maydica. (2005) 50:225-34. Available online at: https://hal.inrae.fr/hal02675620

16. Rodríguez VM, Soengas P, Landa A, Ordas A, Revilla P. Effects of selection for color intensity on antioxidant capacity in maize (Zea mays L.). Euphytica. (2013) 193:339-45. doi: 10.1007/s10681-013-0924-0

17. Vaz Patto MC, Moreira PM, Carvalho V, Pego S. Collecting maize (Zea mays L. convar mays) with potential technological ability for bread making in Portugal. Genet Res Crop E54. (2007) 1555-63. doi: 10.1007/s10722-006-9168-3

18. Vaz Patto MC, Alves ML, Almeida NF, Santos C, Moreira PM, Satovic Z, et al. Is the bread making technological ability of Portuguese traditional maize landraces associated with their genetic diversity? Maydica. (2009) 54:297. Available online at: https://scholar.google.com/scholar?hl=ptPT\&as_sdt $=0 \% 2 \mathrm{C} 5 \& \mathrm{q}=+\mathrm{Vaz}+\mathrm{Patto}+\mathrm{MC} \% 2 \mathrm{C}+$ Alves $+\mathrm{ML} \% 2 \mathrm{C}+\mathrm{Almeida}+$ $\mathrm{NF} \% 2 \mathrm{C}+$ Santos+C\%2C+Moreira+PM\%2C+Satovic $+\mathrm{Z} \% 2 \mathrm{C}+\mathrm{et}+\mathrm{al} .+\mathrm{Is}+$ the + bread+making+technological+ability+of+Portuguese+traditional+maize+ landraces+associated +with+their+genetic+diversity $\% 3 \mathrm{~F}+$ Maydica\&btnG $=$

19. Brites CM, Trigo MJ, Carrapiço B, Alviña M, Bessa RJ. Maize and resistant starch enriched breads reduce postprandial glycemic responses in rats. Nutr Res. (2011) 31:302-8. doi: 10.1016/j.nutres.2011.02.001

20. Brites C, Trigo MJ, Santos C, Collar C, Rosell CM. Maizebased gluten-free bread: influence of processing parameters on sensory and instrumental quality. Food Bioprocess Technol. (2010) 3:707-15. doi: 10.1007/s11947-008-0108-4

21. Cunha LM, Fonseca SC, Lima RC, Loureiro J, Pinto AS, Vaz Patto $\mathrm{MC}$, et al. Consumer driven improvement of maize bread formulations with legume fortification. Foods. (2019) 8:235. doi: 10.3390/foods 80 70235

22. Modesto ML. Traditional Portuguese Cooking. Verbo, Lisbon, Portugal (1989).

23. Périgord A. Du maïs paysan dans mon assiette! (re) découvrez une céréale aux qualités insoupçonnées dans toute sa diversité! Ed. du Terran, Escalquens, France (2016).

24. Bekrić V. Upotreba kukuruza. Maize Research Institute Zemun Polje', Belgrad, Sebia CIP (1997)

25. Radosavljević M, Filipović N, BoŽović I, Jovanović R. Utilization possibility of different ZP maize genotypes in bread production. J Process Energy Agric. (2003) 7:1-2. Available online at: http://rik.mrizp.rs/bitstream/handle/ 123456789/70/68.pdf? sequence=1\&isAllowed $=y$

26. Filipović N, Šoronja-Simović D, Filipović J. Bread with extruded corn products. Acta Agriculturae Serbica. (2006) 11:29-36. Available online at: https://scindeks.ceon.rs/article.aspx?artid=0354-95420621029F

27. Miyazaki M, Morita N. Effect of heat-moisture treated maize starch on the properties of dough and bread. Food Res Int. (2005) 38:36976. doi: 10.1016/j.foodres.2004.10.015

28. Simić M, Žilić S, Šimurina O, Filipčev B, Škrobot D, Vančetović J. Effects of anthocyanin-rich popping maize flour on the phenolic profile and the antioxidant capacity of mix-bread and its physical and sensory properties. Polish J Food Nutr Sci. (2018) 68:289-97. doi: 10.2478/pjfns-2018-0002

29. Žilić S, HadŽi-Tašković Šukalović V, Milašinović M, Ignjatović-Micić D, Maksimović M, Semenčenko V. Effect of micronisation on the composition and properties of white, yellow and red maize flour. Food Technol Biotechnol. (2010) 48:198-206. Available online at: https://ezproxy.nb.rs:3541/ehost/ pdfviewer/pdfviewer?vid=3\&sid $=67 \mathrm{a} 87845-9 \mathrm{c} 7 \mathrm{a}-44 \mathrm{ca}-82 \mathrm{c} 5-$ ad $61 \mathrm{bbc0d} 158$ $\% 40$ redis

30. Žilić S, Ignjatović-Micić D, Saratlić G, Stanković G, Delić N, Filipović M, et al. Protein and tryptophan content in kernels of maize hybrids. Serbian J Agric Sci. (2010) 59:56-64. Available online at: http://rik.mrizp.rs/bitstream/ id/2252/318.pdf

31. Pellati R. Cibi e bevande dalla 'A' alla 'Z'. Milan, Italy: Mondadori (1997).

32. Mc Gee H. On Food and Cooking. New York, U.S.A.: Scribner (2004).

33. Balconi $\mathrm{C}$, Valoti $\mathrm{P}$. La biodiversità in tavola: le varietà antiche doi mais per mille polente. Ricerca e innovazione, Bergamo terra del gusto, Italy (2013).

34. Menéndez-Baceta G, Aceituno-Mata L, Tardio J, Reyes-Garcia V. (2012). Pardo de Santayana, M. Wild edible plants traditionally gathered in Gorbeialdea (Biscay, Basque Country). Genet Resour Crop E. (2012) 59:132947. doi: 10.1007/s10722-011-9760-z

35. De Ruiz G. Characterization of Spanish maize populations according to their agroecological zone of origin. Ann Aula Dei. (1994) 21:81-5.

36. De Ruiz G. Morphological classification of maize landraces from northern Spain Genet Res Crop E. (2001) 48:391-400. doi: 10.1023/A:1012074606561

37. De Ruiz G. Breeding potential of early-maturing flint maize germplasm adapted to temperate conditions. Span J Agric Res. (2010) 8:7481. doi: 10.5424/sjar/2010081-1145

38. Revilla P, de Ruiz G. Mejora de variedades autóctonas de maíz em agricultura convencional y ecológica. Tierras. (2014) 216:78-80.

39. Campo L, Moreno-González J. Ecuaciones NIRS desarrolladas para la estimación del contenido de proteína y almidón en grano de Maíz. En: 53 ${ }^{\text {a }}$ Reunión Científica de la Sociedad Española para el Estudio de los Pastos (SEEP)Pastos y PAC2014-2020, Cantabria, España (2014).

40. Caballero JM, Tejera RL, Caballero AA, Rubio C, González-Weller D, Gutiérrez AJ, et al. Mineral composition of different types of Canarian gofio; factors affecting the presence of $\mathrm{Na}, \mathrm{K}, \mathrm{Mg}, \mathrm{Ca}, \mathrm{Mn}, \mathrm{Fe}, \mathrm{Cu}$ and $\mathrm{Zn}$. Nutr Hosp. (2014) 29:687-94. doi: 10.3305/nh.2014.29.3.7099

41. Suárez MA, Álvarez R, Hardisson A, Sierra A. Valor nutritivo del gofio. Nutrición Clínica. (1990) 4:31-44.

42. Viera y Clavijo J. Diccionario de Historia Natural de las Islas Canarias. Ed. Nivaria. Tenerife., Spain (2004). p. 639.

43. Salinas-Moreno Y, Martinos-Bustos F, Soto-Hernandez M, Ortega-Paczka R, Arellano-Vazquez JL. Effect of alkaline cooking process on anthocyanins in pigmented maize grain. Agrosciencia. (2003) 37:617-28.

44. Código Alimentario Espanñol. Harinas y derivados (Cap XX) Gofio (Sección III, artículo 3, 20.35. Boletin Oficial del Estado, Madrid, Spain (1967). 
45. Febles CI, Arias A, Hardisson A, Rodríguez-Alvarez C, Sierra A. Phytic acid level in edible grain derivatives in the Canary Islands (gofio and frangollo). Eur Food Res Technol. (2000) 210:346-8. doi: 10.1007/s002170050561

46. García-Luis JC. Del grano al gofio. pp. 144. Centro de Conservación de la Biodiversidad Agrícola de Tenerife. Cabildo Insular de Tenerife, Spain (2005).

47. Cerpa O, Millán R, Sanjuán E. Estudio de la aceptabilidad del gofio en Gran Canaria. Reista Canaria de las Ciencias Veterinarias. (2011) 1:27-34.

48. Žilić S, Janković M, Basić Z, Vančetović J, Maksimović V. Antioxidant activity, phenolic profile, chlorophyll and mineral matter content of corn silk (Zea mays L): comparison with medical herbs. J Cereal Sci. (2016) 69:363-70. doi: 10.1016/j.jcs.2016.05.003

49. Radosavljević M, BoŽović I, Jovanović R, Bekrić V, Žilić S, Terzić D. Highquality food and new technical products based on maize and soybean. $J$ Process Energy Agric. (2002) 6:54-60. Available online at: https://rik.mrizp. $\mathrm{rs} /$ bitstream/handle/123456789/34/32.pdf? sequence $=1$ \&isAllowed $=\mathrm{y}$

50. Semenčenko V, Mojović Lj, Đć-Vuković A, Radosavljević M, Terzić D, Milašinović Šeremešić M. Suitability of some selected maize hybrids from Serbia for the production of bioethanol and dried distillers' grains with solubles. J Sci Food Agric. (2013) 93:811-8. doi: 10.1002/jsfa.5801

51. Statistics Portugal. Estatísticas da produção vegetal (2020). Available online at: www.ine.pt (accessed September 08, 2020).

52. Statistics Portugal. Contas Nacionais da Agricultura (2020). Available online at: www.ine.pt (accessed September 08, 2020).

53. Statistics Portugal. Balanços de aprovisionamento de produtos vegetais (2020). Available online at: www.ine.pt (accessed September 08, 2020).

54. Dinis I, Mendes-Moreira P, Padel S. Developing marketing strategies for food diversity: a case-study in Northern Portugal. In: Rural development 2017: bioeconomy challenges. Proceedings of the 8th international scientific conference, 23-24 November, 2017, Aleksandras Stulginskis University,Lithuania, 985-991 (2017).

55. Kean EG, Hamaker BR, Ferruzzi MG. Carotenoid bioaccessibility from whole grain and degermed maize meal products. J Agric Food Chem. (2008) 56:9918-26. doi: 10.1021/jf8018613

56. Perichart-Pereira O, Balas-Nakash M, Rodríguez-Cano A, Muñoz-Manrique A, Monge-Urrea C, Vadillo-Ortega F. Correlates of dietary energy sources with cardiovascular disease risk markers in Mexican school-age children. J Am Diet Assoc. (2010) 110:253-60. doi: 10.1016/j.jada.2009. 10.031

57. Revilla P, Landa A, Rodríguez VM, Romay MC, Ordas A, Malvar RA. Maize for bread under organic agriculture. Spanish J Agric Res. (2008) 6:241-7. doi: 10.5424/sjar/2008062-315

58. Garzon R, Rosell CM, Malvar RA, Revilla P. Diversity among maize populations from Spain and the United States for dough rheology and gluten-free breadmaking performance. Int J Food Sci Technol. 52:10008. doi: 10.1111/ijfs.13364

59. Moreira R, Chenlo F, Arufe S, Rubinos SN. Physicochemical characterization of white, yellow and purple maize flours and rheological characterization of their doughs. J Food Sci Technol. (2015) 52:7954-63. doi: 10.1007/s13197-015-1953-6

60. Vaz Patto MC, Mendes-Moreira PM, Alves ML, Mecha E, Brites C, Bronze R. Participatory plant quality breeding: An ancient art revisited by knowledge sharing. The Portuguese experience. In: Andersen SB, editors. Plant Breeding From Laboratories to Fields. Rijeka, Croatia: InTech (2013). p. 255-88

61. Alves ML, Brites C, Paulo M, Carbas B, Belo M, Mendes-Moreira P. Setting up decision-making tools towards a quality-oriented participatory maize breeding program. Frontiers Plant Sci. (2017) 8:2203. doi: $10.3389 /$ fpls.2017.02203

62. Venturelli MB, Purin B, Pirola M. Maize for the production of polenta flour. Inf Agrario. (1990) 46:128-9.

63. Brandolini A, Brandolini A. Maize introduction, evolution and diffusion in Italy. Maydica. (2009) 54:233-42.

64. Zeppa G, Bertolino M, Rolle L. Quantitative descriptive analysis of Italian polenta produced with different corn cultivars. J Sci Food Agr. (2012) 92:4127. doi: $10.1002 /$ jsfa.4593

65. Berardo N, Mazzinelli G, Valoti P, Laganà P, Redaelli R. Characterisation of maize germplasm for the chemical composition of the grain. J Agric Food Chem. (2009) 57:2378-84. doi: 10.1021/jf803688t
66. Alfieri M, Hidalgo A, Berardo N, Redaelli R. Carotenoid composition and heterotic effect in selected Italian maize germplasm. J Cereal Sci. (2014) 59:181-8. doi: 10.1016/j.jcs.2013.12.010

67. Babić V, Kravić N, Vančetović J, Delić N, Žilić S. Differences in nutritive and bioactive compounds content between hybrid and openpollinated maize varieties. Food Feed Res. (2020) 47:1-12. doi: 10.5937/ FFR2001001B

68. Žilić S, Serpen A, Akillioglu G, Gökmen V, Vančetović J. Phenolic compounds, carotenoids, anthocyanins, and antioxidant capacity of colored maize (Zea mays L.) kernels. J Agric Food Chem. (2012) 60:122431. doi: 10.1021/jf204367z

69. Žilić S, Ataç Mogol B, Akillioglu G, Serpen A, Babić M, Gökmen V. Effects of infrared heating on phenolic compounds and Maillard reaction products in maize flour. J Cereal Sci. (2013) 58:1-7. doi: 10.1016/j.jcs.2013.05.003

70. Žilić S, Delić N, Basić Z, Ignjatović-Micić D, Janković M, Vančetović J. Effects of alkaline cooking and sprouting on bioactive compounds, their bioavailability and relation to antioxidant capacity of maize flour. J Food Nutr Res. (2015) 54:155-64. Available online at: https://ezproxy.nb.rs: 3541/ehost/pdfviewer/pdfviewer?vid=3\&sid=d73a5341-5182-4c37-a1637dee03d84ace\%40redis

71. Mladenović Drinić S, Andelković V, Ignjatović-Micić D. Genetic Diversity of Maize Landraces as a Source of Favorable Triats. In: Genetic Diversity, Book 2, ed. Prof. Dr. Mahmut Caliskan Mustafa Kemal University, Department of Biology Hatay, Turkey, published by InTech (2011). p.89-112

72. Ignjatović-Micić D, Kostadinović M, BoŽinović S, Andelković V, Vančetović J. High grain quality accessions within a maize drought tolerant core collection. Sci Agr. (2014) 71:402-9. doi: 10.1590/0103-9016-2013-0112

73. Smith JR. 50. of the world's best breads. CNN Travel (2020). Available online at: https://edition.cnn.com/travel/article/world-50-best-breads/index.html (accessed September 08, 2020)

74. Simas KND, Vieira LN, Podestá R, Müller C, Vieira MA, Beber RC, et al. Effect of king palm (Archontophoenixalexandrae) flour incorporation on physicochemical and textural characteristics of gluten-free cookies. Int J Food Sci. (2009) 44:531-8. doi: 10.1111/j.1365-2621.2008.01840.x

75. Mendoza N, McGough N. Coeliac disease: An overview. Nutr Food Sci. (2005) 35:156-62. doi: 10.1108/00346650510594903

76. Arentz-Hansen H, Korner R, Molberg O, Quarsten H, Vader W, Kooy YM. The intestinal $\mathrm{T}$ cell response to alpha-gliadin in adult celiac disease is focused on a single deamidated glutamine targeted by tissue transglutaminase. J Exp Med. (2000) 191:603-12. doi: 10.1084/jem.191.4.603

77. Alaedini A, Green PH. Narrative review: coeliac disease: understanding a complex autoimmune disorder. Ann Intern Med. (2005) 142:28998. doi: 10.7326/0003-4819-142-4-200502150-00011

78. Mena MC, Lombardia M, Hernando A, Mendez E, Albar JP. Comprehensive analysis of gluten in processed foods using a new extraction method and a competitive ELISA based on the R5 antibody. Talanta. (2012) 91:3340. doi: 10.1016/j.talanta.2011.12.073

79. Torres MD, Arufe S, Chenlo F, Moreira R. Coeliacs cannot live by gluten-free bread alone - every once in a while they need antioxidants. Int J Food Sci Technol. (2017) 52:81-90. doi: 10.1111/ijfs.13287

80. Ortiz Sánchez JP, Mata Haro V, Cabrera Chávez F, Calderón de la Barca AM. Prolamins of maize and wheat differentially affect intestinal cells both in biopsies of celiac patients and CACO-2 cell line. Food Agric Immunol. (2016) 27:259-72. doi: 10.1080/09540105.2015.1086316

81. Harjes CE, Rocheford TR, Bai L, Brutnell TP, Kandianis CB, Sowinski SG. Natural genetic variation in lycopene epsilon cyclase tapped for maize biofortification. Science. (2008) 319:330-3. doi: 10.1126/science.1150255

82. Egesel CO, Wong RJ, Rocheford TR. Combining Ability of Maize Inbreds for Carotenoids and Tocopherols. Crop Sci. (2003) 43:818. doi: $10.2135 /$ cropsci2003.8180

83. Žilić S, Kocadagli T, Vančetović J, Gökmen V. The effects of baking conditions and dough formulations on phenolic compounds stability, antioxidant capacity and color of cookies made from anthocyanin-rich corn flour. LWT-Food Sci. Technol. (2016) 65:597-603. doi: 10.1016/j.lwt.2015.08.057

84. Kocadagli T, Žilić S, Göncüoglu, Taş N, Vančetović J, Dodig D, Gökmen V. Formation of $\alpha$-dicarbonyl compounds in cookies made from wheat, hullless barley and colored corn and its relation with phenolic compounds, 
free amino acids and sugars. Eur Food Res Technol. (2016) 241:5160. doi: 10.1007/s00217-015-2517-8

85. Žilić S, Gürsul Aktag I, Dodig D, Filipović M, Gökmen V. Acrylamide formation in biscuits made of different whole grain flours depending on their free asparagine content and baking conditions. Food Res Int. (2020) 132:109. doi: 10.1016/j.foodres.2020.109109

86. Regione Lombardia (2002). Mais in Lombardia: varietà tradizionali. Quaderni della ricerca. Qdr n.21. Available online at: http://www.agricoltura. regione.lombardia.it/shared/ccurl/770/775/QdR_21_MAIS.pdf (accessed September 08, 2020)

87. Torri A, Lanzanova C, Locatelli S, Valoti P, Balconi C. Screening of local Italian maize varieties for resistance to Fusarium verticillioides. Maydica. (2015) 60:1-8.

88. Balconi C, Valoti P, Pecchioni N. La biodiversità del mais: una grande opportunità doi cooperazione internazionale tra Italia e Bolivia. Mangimi and Alimenti. (2019) 14-6.

89. Lago C, Cassani E, Zanzi C, Landoni M, Trovato R, Pilu R. Development and study of maize cultivar rich in anthocyanins: coloured polenta, a new functional food. Plant Breed. (2014) 133:210-7. doi: 10.1111/pbr.12153

90. Suriano S, Balconi C, Valoti P, Redaelli R. Comparison of total polyphenols, profile anthocyanins, color analysis, carotenoids and tocols in pigmented maize. LWT. (2021) 144:111257. doi: 10.1016/j.lwt.2021.111257

91. Navarro A, Torres A, Fernández-Aulis F, Peña C. 2. Bioactive compounds in pigmented maize. In 'Corn - Production and Human Health in Changing Climate. IntechOpen (2018).

92. Jones RB. Effects of postharvest handling conditions and cooking on anthocyanin, ycopene, and glucosinolate content and bioavailability in fruits and vegetables. NZ J Crop Hortic Sci. (2007) 35:219-27. doi: 10.1080/01140670709510188

93. Žilić S, Dodig D, Vančetović J, Grčić N, Perić V, Titan P, et al. Composition of Anthocyanins in colored grains and the relationship of their nonacylated and acylated derivatives. Pol J Food Nutr Sci. (2019) 69:13746. doi: 10.31883/pjfns-2019-105100

94. Collar C. Barley, Maize, Sorghum, Millet, and Other Cereal Grains. Bakery Products Science and Technology, 2nd Edition (2014).

95. Collar C, Balestra F, Ancarani D. Value Added of Resistant Starch MaizeBased Matrices in Breadmaking: Nutritional and Functional Assessment. Food Bioprocess Technol. (2014) 7:3579-90. doi: 10.1007/s11947-014-1371-1

96. Bento-Silva A. Relevance, structure and analysis of ferulic acid in maize cell walls. Food Chem. (2018) 246:360-78. doi: 10.1016/j.foodchem.2017.11.012

97. Bento-Silva A, Mecha E, Belo M, Nunes A, Carbas B, Serra T. Broa, a Portuguese ethnic maize bread, as an improved source of soluble phenolic compounds. LWT-Food Sci. Technol. (2021) 10:121. doi: $10.3390 /$ antiox 10050672

98. Tafuri A, Alfieri M, Redaelli R. Determination of soluble phenolics content in Italian maize varieties and lines. Tecn Molitoria Intern. (2014) 65:60-9.

99. Adom KK, Liu RH. Antioxidant activity of grains. J Agric Food Chem. (2002) 50:6182-7. doi: 10.1021/jf0205099

100. Serpen A, Capuano E, Fogliano V, Gokmen V. A new procedure to measure the antioxidant activity of insoluble food components J. Agric Food Chem. (2007) 55:7676-81. doi: 10.1021/jf071291z

101. Lu X, Rasco BA. Determination of antioxidant content and antioxidant activity in foods using Infrared Spectroscopy and chemometrics: a review. Crit Rev Food Sci Nutr. (2012) 52:853-75. doi: 10.1080/10408398.2010.511322

102. Redaelli R, Alfieri M, Cabassi G. Development of a NIRS calibration for total antioxidant capacity in maize germplasm. Talanta. (2016) 154:1648. doi: 10.1016/j.talanta.2016.03.048

103. Masure HG, Fierens E, Delcour JA. Current and forward looking experimental approaches in gluten-free bread making research. J Cereal Sci. (2016) 67:92-111. doi: 10.1016/j.jcs.2015.09.009

104. Roman L, Belorio M, Gomez M. Gluten-Free breads: The gap between research and commercial reality. Compreh Rev Food Sci Food Saf. (2019) 18:690-702. doi: 10.1111/1541-4337.12437

105. Waterschoot J, Gomand SV, Fierens E, Delcour JA. Production, structure, physicochemical and functional properties of maize, cassava, wheat, potato and rice starches. Starch/Stärke. (2015) 67:14-29. doi: 10.1002/star.201300238
106. Alfieri M, Bresciani A, Zanoletti M, Pagani MA, Marti A, Redaelli R. Physical, chemical and pasting features of maize Italian inbred lines. Eur Food Res Technol. (2020) 246:2205-14. doi: 10.1007/s00217-020-03565-1

107. Revilla P, Garzon R, Rosell CM, Malvar RA. Effects of high amylopectin (waxyl) and high-quality protein (opaque2) maize mutants in agronomic performance and bakery quality. J Cereal Sci. (2019) 89:102796. doi: $10.1016 /$ j.jcs.2019.102796

108. FAO. Manual on the application of the HACCP (Hazard Analysis Critical Control Point) system in mycotoxin prevention and control. FAO Food and Nutrition paper 73, Rome, Italy (2001). Available online at: http://www.fao. org/docrep/005/y1390e/y1390e00.htm

109. FAO. Worldwide regulations for mycotoxins in food and feed. FAO Food and Nutrition paper 81, Rome, Italy (2004). Available online at: http://www. fao.org/docrep/007/y5499e/y5499e00.htm

110. Balazs E, Schepers JS. The mycotoxin threat to world safety. Int J Food Microbiol. (2007) 119:1-2. doi: 10.1016/j.ijfoodmicro. 2007.07.018

111. Castegnaro M, McGregor D. Carcinogenic risk assessment of mycotoxins. Revue de Med veterinaire. (1998) 149:671-8.

112. Ostry V, Malir F, Toman J, Grosse Y. Mycotoxins as human carcinogens. The IARC Monographs classification Mycotoxin Res. (2017) 33:65-73. doi: 10.1007/s12550-016-0265-7

113. Vendl O, Crews C, MacDonald S, Krska R, Berthiller F. Occurrence of free and conjugated Fusarium mycotoxins in cereal-based food. Food Add Contam. (2010) 27:1148. doi: 10.1080/19440041003801166

114. Schothorst RC, van Egmond HP. Report from SCOOP task 3.2.10 'collection of occurrence data of Fusarium toxins in food and assessment of dietary intake by the population of EU member states' Subtask: trichothecenes. Toxicol Letters. (2004) 153:133. doi: 10.1016/j.toxlet.2004.04.045

115. Van Egmond HP, Schothorst RC, Jonker MA. Regulations relating to mycotoxins in food. Anal Bioanal Chem. (2007) 389:147. doi: 10.1007/s00216-007-1317-9

116. Duncan KE, Howard RJ. Biology of maize kernel infection by Fusarium verticillioides. Mol Plant Microbe Interact. (2010) 1:6-16. doi: 10.1094/MPMI-23-1-0006

117. Balconi C, Motto M, Mazzinelli G, Berardo N. Ear secondary traits related to aflatoxin accumulation in commercial maize hybrids under artificial field inoculation. World Mycot. (2010) 3:239-50. doi: 10.3920/WMJ2010.1205

118. Balconi C, Berardo N, Locatelli S, Lanzanova C, Torri A, Redaelli R. Evaluation of ear rot (Fusarium verticilliodes) resistance and fumonisin accumulation in Italian maize inbred lines. Phytopathol Med. (2014) 53:1426. doi: 10.14601/phytopathol_Mediterr-11776

119. Azaiez I, Meca G, Manyes L, Fernandez-Franzon M. Antifungal activity of gaseous allyl, benzyl and phenyl isothiocyanate in vitro and their use for fumonisins reduction in bread. Food Control. (2013) 32:42834. doi: 10.1016/j.foodcont.2013.01.020

120. Manyes L, Ruiz MJ, Luciano FB, Meca G. Bioaccessibility and bioavailability of fumonisin B-2 and its reaction products with isothiocyanates through a simulated gastrointestinal digestion system. Food Control. (2013) 37:32635. doi: 10.1016/j.foodcont.2013.09.056

121. Jackson LS, Hlywka JJ, Senthil KR, Bullerman LB, Musser SM. Effects of Thermal Processing on the Stability of Fumonisin B22in in an Aqueous System an Aqueous System. I Agric Food Chem. (1996) 44:906. doi: 10.1021/jf950364o

122. Fandohan P, Zoumenou D, Hounhouigan DJ, Marasas WFO, Wingfield MJ, Hell K. Fate of aflatoxins and fumonisins during the processing of maizeinto food products in Benin. Int J Food Microbiol. (2005) 98:249. doi: 10.1016/j.ijfoodmicro.2004.07.007

123. Krska R, de Nijs M, McNerney O, Pichler M, Gilbert J, Edwards S, et al. Safe food and feed through an integrated toolbox for mycotoxin management: The MyToolBox approach. World Mycotoxin J. (2016) 9:48795. doi: 10.3920/WMJ2016.2136

124. Lino CM, Silva LJG, Pena A, Fernandez M, Manes J. Occurrence of fumonisins B-1 and B-2 in broa, typical Portuguese maize bread. Int J Food Microbiol. (2007) 118:79-82. doi: 10.1016/j.ijfoodmicro.2007.04.014

125. Juan C, Pena A, Lino C, Molto JC, Manes J. Levels of ochratoxin A in wheat and maize bread from the central zone of Portugal. Int J Food Microbiol. (2008) 127:284-9. doi: 10.1016/j.ijfoodmicro.2008.07.018 
126. Duarte SC, Tanello A, Pena A, Lino CM, Matos CD, Oliveira MBPP, et al. Evaluation of ochratoxin A exposure degree in two Portuguese cities through wheat and maize bread consumption during the winter 2007. Food Control. (2010) 21:702. doi: 10.1016/j.foodcont.2009.10.011

127. Juan C, Lino CM, Pena A, Molto JC, Manes J, Silveira I. Determination of ochratoxin A in maize bread samples by LC with fluorescence detection. Talanta. (2007) 73:246-50. doi: 10.1016/j.talanta.2007.03.029

128. Lisker N, Lillehoj EB. Prevention of mycotoxin contamination (principally aflatoxin and Fusarium toxins) at the pre-harvest stage. In: Smith JE, Henderson RS, editors. Mycotoxins and animal foods. CRC Press, Boca Raton, U.S.A. (1991). p. 689-719

129. Jouany JP. Mycotoxigenic Fusarium species in animal feed. An Feed Sci Technol. (2007) 137:342. doi: 10.1016/j.anifeedsci.2007.06.009

130. Cao A, Santiago R, Ramos AJ, Marin S, Reid LM, Butrón A. Environmental factors related to fungal infection and fumonisin accumulation during the development and drying of white maize kernels. Int J Food Microbiol. (2013) 164:15-22. doi: 10.1016/j.ijfoodmicro.2013.03.012

131. Butrón A, Revilla P, Sandoya G, Ordás A, Malvar RA. Resistance to reduce corn borer damage in maize for bread, in Spain. Crop Protection. (2009) 28:134-8. doi: 10.1016/j.cropro.2008.09.007

132. Herrera M, van Dam R, Spanjer M, de Stoppelaar J, Mol H, de Nijs M, et al. Survey of moniliformin in wheat- and corn-based products using a straightforward analytical method. Mycotoxin Research. (2017) 33:33341. doi: 10.1007/s12550-017-0287-9

133. de Ruiz G. Mycotoxins in maize grains grown in organic and conventional agriculture. Food Control. (2014) 52:98102. doi: 10.1016/j.foodcont.2014.12.016

134. Santiago R, Cao A, Malvar RA, Butrón A. Assessment of corn resistance to fumonisin accumulation in a broad collection of inbred lines. Field Crop Res. (2013) 149:193-202. doi: 10.1016/j.fcr.2013.04.011

135. Pilu R, Cassani E, Sirizzotti A, Petroni K, Tonelli C. Effect of flavonoid pigments on the accumulation of fumonisin B1 in the maize kernel. J Appl Genetics. (2011) 52:145-52. doi: 10.1007/s13353-010-0014-0

136. Nesci M, Montemarani A, Passone MA, Etcheverry M. Insecticidial activity of synthetic antioxidants. Natural phytochemicals, and essential oils against an Aspergillus section Flavi vector (Oryzaephilus surinmensis L) in microcosm. J Pest Sci. (2012) 84:107-15. doi: 10.1007/s10340-010-0333-2

137. Swiatek M, Kielkiewicz M, Zagdanska B. Insect-resistant Bt-maize response to the short-term non -target mite-pest onfestation and soil drought. Acta Physiol Plant. (2014) 36:2705-15. doi: 10.1007/s11738-014-1641-6

138. Revilla P, Soenga P, Malvar RA. Effects of antioxidant activity of black maize in corn borer larval survival and growth. Spanish J Agric Res. (2018) 16:1004-11. doi: 10.5424/sjar/2018161-11939

139. Landoni M, Puglisi D, Cassani E, Borlini G, Brunoldi G, Comaschi $\mathrm{C}$, et al. Phlobaphenes modify pericarp thickness in maize and accumulation of the Fumonisin mycotoxins. Sci Rep. (2020) 10:1417. doi: 10.1038/s41598-020-58341-8

140. Cassani E, Puglisi D, Cantaluppi E, Landoni M, Giupponi L, Giorgi A, et al. Genetic studies regarding the control of seed pigmentation of an ancient European pointed maize (Zea mays L.) rich in phlobaphenes: the 'Nero Spinoso' from the Camonica valley. Genet. Resour Crop E. (2017) 64:761-73. doi: 10.1007/s10722-016-0399-7

141. Garcia-Oliveira AL, Poschenrieder C, Barcelo J, Martins-Lopes P. Breeding for Al Tolerance by Unravelling Genetic Diversity in Bread Wheat. Aluminum Stress Adaptation in Plants. (2015) 24:125-53. doi: 10.1007/978-3-319-19968-9_7

142. Bouza-Brey F. Noticias históricas sobre la introducción del cultivo del maíz en Galicia. Bol Real Acad Hist. (1953) 132:35-72.

143. FAO. Maize in Human Nutrition. Rome, Italy: Food and Agriculture Organization of the United Nations (1992).

144. Oladunmoye OO, Akinoso R, Olapade AA. Evaluation of some physical-chemical properties of wheat, cassava, maize and cowpea flours for bread making. J Food Quality. (2010) 33:693-708. doi: 10.1111/j.1745-4557.2010.00351.x

145. Thompson DL, Goodman MM. Increasing Kernel Density for Two Inbred Lines of Maize. Crop Sci. (2006) 46:2179. doi: 10.2135/cropsci2006. 02.0111
146. Carbas B, Vaz Patto MC, Bronze MR, da Bento S. Maize flour parameters that are related to the consumer perceived quality of 'broa' specialty bread. Food Sci Technol. (2016) 36:259-67. doi: 10.1590/1678-457X.6674

147. Oladunmoye OO, Ojo A, Akinoso R, Akanbi CT. Thermo-physical properties of compo-site bread dough with maize and cassava flours. Int J Food Sci Technol. (2010) 45:587-93. doi: 10.1111/j.1365-2621.2010.02171.x

148. Butrón A, Romay MC, Ordás A, Malvar RA, Revilla P. Genetic and environmental factors for reducing the incidence of the maize storage pest Sitotroga cerealella (Olivier). Entomol Exp Appl. (2008) 128:4218. doi: 10.1111/j.1570-7458.2008.00733.x

149. Alonso Ferro RC, Malvar RA, Revilla P, Ordás A, Castro P, Moreno-González J. Genetics of quality and agronomic traits in hard endosperm maize. J Agric Sci. (2008) 146:551-60. doi: 10.1017/S0021859608007934

150. Konings WN, Kok J, Kuipers OP, Poolman B. Lactic acid bacteria: the bugs of the new millennium. Curr Opin Microbiol. (2000) 3:27682. doi: 10.1016/S1369-5274(00)00089-8

151. Vogel RF, Ehrmann MA, Ganzle MG. Development and potential of starter lactobacilli resulting from exploration of the sourdough ecosystem. Antonie Van Leeuwenhoek. (2002) 81:631-8. doi: 10.1023/A:1020530227192

152. Pepe O, Villani F, Oliviero D, Greco T, Coppola S. Effect of proteolytic starter cultures as leavening agents of pizza dough. Int J Food Microbiol. (2003) 84:319-26. doi: 10.1016/S0168-1605(02)00473-7

153. Pico J, Martinez MM, Bernal J, Gomez M. Evolution of volatile compounds in gluten-free bread: From dough to crumb. Food Chem. (2017) 227:17986. doi: 10.1016/j.foodchem.2017.01.098

154. Revilla P, Landa A, Rodríguez A, Ordas A, Malvar RA. Influence of Growing and Storage Conditions on Bakery Quality of Traditional Maize Varieties under Organic Agriculture. Crop Sci. (2015) 52:593600. doi: 10.2135/cropsci2011.03.0182

155. De la Hera E, Talegon M, Caballero P, Gomez M. Influence of maize flour particle size on gluten-free breadmaking. J Sci Food Agric. (2013) 93:92432. doi: $10.1002 /$ jsfa.5826

156. Mancebo CM, Merino C, Martinez MM, Gomez M. Mixture design of rice flour, maize starch and wheat starch for optimization of gluten free bread quality. J Food Sci Technol. (2015) 52:6323-33. doi: 10.1007/s13197-015-1769-4

157. Mariani-Costantini R, Mariani-Costantini A. An outline of the history of pellagra in Italy. J Anthropol Sci. (2007) 85:163-71.

158. Pitche PT. Pellagre et érythèmes pellagroïdes [Pellagra]. Sante. (2005) 15:3.

159. World Health Organization. Pellagra and Its Prevention and Control in Major Emergencies. (2020). Available online at: https://www.unhcr.org/4cbeefad9. pdf (accessed September 08 2020).

160. Sydenstricker VP. The history of pellagra, its recognition as a disorder of nutrition and its conquest. Am J Clin Nutr. (1958) 6:409-14. doi: 10.1093/ajcn/6.4.409

161. Moreira PMRM, Pego SE, Vaz Pato MC, Hallauer AR. Comparison of selection methods on 'Pigarro', a Portuguese improved maize population with fasciation expression. Euphytica. (2008) 163:481. doi: 10.1007/s10681-008-9683-8

162. Mendes-Moreira PM, Satovic Z, Mendes-Moreira J, Santos JP, Nina P. Maize participatory breeding in Portugal. Comparison of farmer's and breeder's on-farm selection Plant Breed. (2017) 136:861-71. doi: 10.1111/pbr.12551

163. Alves ML, Belo M, Carbas B, Brites C, Paulo M, Mendes-Moreira P, et al. Long-term on-farm participatory maize breeding by stratified mass selection retains molecular diversity while improving agronomic performance. Evol Applications. (2018) 11:254-70. doi: 10.1111/eva.12549

164. Mendes-Moreira PM, Vaz Patto MC, Mota M, Mendes-Moreira J, Santos JPN, Santos JPP, et al. Fandango: long term adaptation of exotic germplasm to a portuguese on-farm-conservation and breeding project. Maydica. (2009) 54:269-85. Available online at: https://hdl.handle.net/10216/44277

165. Vaz Patto MC, Moreira PM, Almeida N, Satovic Z, Pego S. Genetic diversity evolution through participatory maize breeding in Portugal. Euphytica. (2008) 161:283-91. doi: 10.1007/s10681-007-9481-8

166. Mendes-Moreira PM, Mendes-Moreira J, Fernandes A, Andrade E, Hallauer AR, Pêgo SE, et al. Is ear value an effective indicator for maize yield evaluation? Field Crops Res. 161:75-86. doi: 10.1016/j.fcr.2014. 02.015 
167. Clements MJ, White DG. Identifying Sources of Resistance to Aflatoxin and Fumonisin Contamination in Corn Grain. Toxin Rev. (2004) 23:381. doi: 10.1081/TXR-200027865

168. Eller MS, Payne GA, Holland JB. Selection for Reduced Fusarium Ear Rot and Fumonisin Content in Advanced Backcross Maize Lines and Their Topcross Hybrids. Crop Sci. (2010) 50:2249. doi: 10.2135/cropsci2009.11.0683

169. Muzhingi T, Palacios-Rojas N, Miranda A, Cabrera ML, Yeum KJ, Tang G. Genetic variation of carotenoids, vitamin E and phenolic compounds in Provitamin A biofortified maize. J Sci Food Agric. (2017) 97:793801. doi: 10.1002/jsfa.7798

170. Wen W, Brotman Y, Willmitzer L, Yan J, Fernie AR. Broadening our portfolio in the genetic improvement of maize chemical composition. Trends in Genetics. (2016) 32:459-69. doi: 10.1016/j.tig.2016.05.003

171. Alves ML, Carbas B, Gaspar D, Paulo M, Brites C, Mendes-Moreira P. Genome-wide association study for kernel composition and flour pasting behavior in wholemeal maize flour. BMC Plant Biol. (2019) 19:123. doi: 10.1186/s12870-019-1729-7

172. Alves ML, Bento-Silva A, Gaspar D, Paulo M, Brites C, Mendes-Moreira P. Volatilome-genome-wide association study on wholemeal maize flour. $J$ Agric Food Chem. (2020) 68:7809-18. doi: 10.1021/acs.jafc.0c01273

173. Alves ML, Bento-Silva A, Carbas B, Gaspar D, Paulo M, Brites C. Alleles to enhance antioxidant content in maize-a genome-wide association approach. J Agric Food Chem. (2020) 68:4051-61. doi: 10.1021/acs.jafc.9b07190

174. Andelković V, Masarović J, Srebrić M, Mladenović Drinić S. Pigmented maize - a potential source of $\beta$-carotene and $\alpha$-tocopherol. J Eng Process Manag. (2018) 10:1-7. doi: 10.7251/JEPM181002001A

175. Grosset J, Alary R, Gautier MF, Menossi M, Martinez Izquierdo JA, Joudrier P. Characterization of a barley gene coding for an alpha-amylase inhibitor subunit (CMd protein) and analysis of its promoter in transgenic tobacco plants and in maize kernels by microprojectile bombardment. Plant Mol Biol. (1997) 34:331-8. doi: 10.1023/A:1005811111719

176. Rizwan M, Ali S, Qayyum MF. Use of maize (Zea mays L.) for phytomanagement of Cd-contaminated soils: a critical review. Environ Geochem Health. (2017) 39:259-77. doi: 10.1007/s10653-0169826-0

177. Perrino EV, Brunetti G, Farrag K. Plant communities of multi-metal contaminated soils: a case study in National Park of Alta Murgia (Apulia Region - southern Italy). Int J Phytoremediation. (2014) 16:87188. doi: 10.1080/15226514.2013.798626

Conflict of Interest: The authors declare that the research was conducted in the absence of any commercial or financial relationships that could be construed as a potential conflict of interest.

Publisher's Note: All claims expressed in this article are solely those of the authors and do not necessarily represent those of their affiliated organizations, or those of the publisher, the editors and the reviewers. Any product that may be evaluated in this article, or claim that may be made by its manufacturer, is not guaranteed or endorsed by the publisher.

Copyright (C) 2022 Revilla, Alves, Andelković, Balconi, Dinis, Mendes-Moreira, Redaelli, Ruiz de Galarreta, Vaz Patto, Žilić and Malvar. This is an open-access article distributed under the terms of the Creative Commons Attribution License (CC $B Y)$. The use, distribution or reproduction in other forums is permitted, provided the original author(s) and the copyright owner(s) are credited and that the original publication in this journal is cited, in accordance with accepted academic practice. No use, distribution or reproduction is permitted which does not comply with these terms. 